\title{
Evaluation of air-soil temperature relationships simulated by land surface models during winter across the permafrost region
}

\author{
Wenli Wang ${ }^{1}$, Annette Rinke ${ }^{1,2}$, John C. Moore ${ }^{1}$, Duoying Ji ${ }^{1}$, Xuefeng Cui ${ }^{3}$, Shushi Peng ${ }^{4,17,18}$, David M. Lawrence ${ }^{5}$, \\ A. David McGuire ${ }^{6}$, Eleanor J. Burke ${ }^{7}$, Xiaodong Chen ${ }^{21}$, Bertrand Decharme ${ }^{9}$, Charles Koven ${ }^{10}$, \\ Andrew MacDougall ${ }^{11}$, Kazuyuki Saito ${ }^{12,15}$, Wenxin Zhang ${ }^{13,19}$, Ramdane Alkama ${ }^{9,16}$, Theodore J. Bohn ${ }^{8}$, \\ Philippe Ciais $^{18}$, Christine Delire ${ }^{9}$, Isabelle Gouttevin ${ }^{4}$, Tomohiro Hajima ${ }^{12}$, Gerhard Krinner $^{4,17}$, \\ Dennis P. Lettenmaier ${ }^{8}$, Paul A. Miller ${ }^{13}$, Benjamin Smith ${ }^{13}$, Tetsuo Sueyoshi ${ }^{14}$, and Artem B. Sherstiukov ${ }^{20}$ \\ ${ }^{1}$ College of Global Change and Earth System Science, Beijing Normal University, Beijing, China \\ ${ }^{2}$ Alfred Wegener Institute Helmholtz Centre for Polar and Marine Research (AWI), Potsdam, Germany \\ ${ }^{3}$ School of System Science, Beijing Normal University, Beijing, China \\ ${ }^{4}$ The Laboratory of Glaciology, French National Center for Scientific Research, Grenoble, France \\ ${ }^{5}$ National Center for Atmospheric Research, Boulder, USA \\ ${ }^{6}$ US Geological Survey, Alaska Cooperative Fish and Wildlife Research Unit, University of Alaska Fairbanks, \\ Fairbanks, AK, USA \\ ${ }^{7}$ Met Office Hadley Centre, Exeter, UK \\ ${ }^{8}$ School of Earth and Space Exploration, Arizona State University, Tempe, AZ, USA \\ ${ }^{9}$ Groupe d'étude de l'Atmosphère Météorologique, Unité mixte de recherche CNRS/Meteo-France, Toulouse cedex, France \\ ${ }^{10}$ Lawrence Berkeley National Laboratory, Berkeley, CA, USA \\ ${ }^{11}$ School of Earth and Ocean Sciences, University of Victoria, Victoria, BC, Canada \\ ${ }^{12}$ Japan Agency for Marine-Earth Science and Technology, Yokohama, Japan \\ ${ }^{13}$ Department of Physical Geography and Ecosystem Science, Lund University, Lund, Sweden \\ ${ }^{14}$ National Institute of Polar Research, Tachikawa, Japan \\ ${ }^{15}$ University of Alaska Fairbanks, Fairbanks, AK, USA \\ ${ }^{16} \mathrm{~L}$ 'Institute for Environment and Sustainability (IES), Ispra, Italy \\ ${ }^{17}$ Université Grenoble Alpes, LGGE, Grenoble, France \\ ${ }^{18}$ Climate and Environment Sciences Laboratory, the French Alternative Energies and Atomic Energy Commission, French \\ National Center for Scientific Research, University of Versailles Saint-Quentin-en-Yvelines, Saclay, France \\ ${ }^{19}$ Center for Permafrost (CENPERM), Department of Geosciences and Natural Resource Management, University of \\ Copenhagen, Copenhagen, Denmark \\ ${ }^{20}$ All-Russian Research Institute of Hydrometeorological Information - World Data Centre, Obninsk, Russia \\ ${ }^{21}$ Department of Civil and Environmental Engineering, University of Washington, Seattle, WA, USA
}

Correspondence to: Duoying Ji (duoyingji@bnu.edu.cn)

Received: 4 February 2016 - Published in The Cryosphere Discuss.: 11 March 2016

Revised: 20 July 2016 - Accepted: 21 July 2016 - Published: 11 August 2016 
Abstract. A realistic simulation of snow cover and its thermal properties are important for accurate modelling of permafrost. We analyse simulated relationships between air and near-surface $(20 \mathrm{~cm})$ soil temperatures in the Northern Hemisphere permafrost region during winter, with a particular focus on snow insulation effects in nine land surface models, and compare them with observations from 268 Russian stations. There are large cross-model differences in the simulated differences between near-surface soil and air temperatures $\left(\Delta T ; 3\right.$ to $\left.14^{\circ} \mathrm{C}\right)$, in the sensitivity of soil-to-air temperature $\left(0.13\right.$ to $\left.0.96{ }^{\circ} \mathrm{C}^{\circ} \mathrm{C}^{-1}\right)$, and in the relationship between $\Delta T$ and snow depth. The observed relationship between $\Delta T$ and snow depth can be used as a metric to evaluate the effects of each model's representation of snow insulation, hence guide improvements to the model's conceptual structure and process parameterisations. Models with better performance apply multilayer snow schemes and consider complex snow processes. Some models show poor performance in representing snow insulation due to underestimation of snow depth and/or overestimation of snow conductivity. Generally, models identified as most acceptable with respect to snow insulation simulate reasonable areas of nearsurface permafrost (13.19 to 15.77 million $\mathrm{km}^{2}$ ). However, there is not a simple relationship between the sophistication of the snow insulation in the acceptable models and the simulated area of Northern Hemisphere near-surface permafrost, because several other factors, such as soil depth used in the models, the treatment of soil organic matter content, hydrology and vegetation cover, also affect the simulated permafrost distribution.

\section{Introduction}

Present-day permafrost simulations by global climate models are limited and future projections contain high, modelinduced uncertainty (e.g. Slater and Lawrence, 2013; Koven et al., 2013). Most of the model biases and cross-model differences in simulating permafrost area are due to inaccurate atmospheric simulation, e.g. of air temperature and precipitation, deficient simulation of snow and soil temperature and the coupling between atmosphere and land surface. In winter, the snow insulation effect is a key process for air-soil temperature coupling. Its strength depends on the snow depth, areal coverage, snow density and conductivity (see overview by Zhang, 2005). Many individual model studies have shown the strong impact of snow parameterisations on soil temperature simulations (e.g. Langer et al., 2013; Dutra et al., 2012; Gouttevin et al., 2012; Essery et al., 2013; Wang et al., 2013; Jafarov et al., 2014). Most importantly, these studies showed that the consideration of wet snow metamorphism and snow compaction, improved snow thermal conductivity and multilayer snow schemes can improve the simulation of snow dynamics and soil temperature. Parameterisations that take into account snow compaction (e.g. related to overburden pressure, thermal metamorphism and liquid water) work better than simpler schemes such as an exponential increase of density with time (Dutra et al., 2010). The influence of snow thermal conductivity on soil temperature has been demonstrated by many model studies (e.g. Bartlett et al., 2006; Saha et al., 2006; Vavrus, 2007; Nicolsky et al., 2007; Dankers et al., 2011; Gouttevin et al., 2012). Winter soil temperature can change by up to $20 \mathrm{~K}$ simply by varying the snow thermal conductivity by $0.1-0.5 \mathrm{~W} \mathrm{~m}^{-1} \mathrm{~K}^{-1}$ (Cook et al., 2008). The snow insulation effect also plays an important role for the Arctic soil temperature response to climate change and therefore for future near-surface permafrost thawing and soil carbon vulnerability (e.g. Schuur et al., 2008). Shallower snow can reduce soil warming while shorter snow season can enhance soil warming (Lawrence and Slater, 2010). The model skill in atmosphere-soil coupling with the concomitant snow cover in the Arctic is an important factor in the assessment of limitations and uncertainty of carbon mobility estimates (Schaefer et al., 2011).

The Snow Models intercomparison project (SnowMIP; Essery et al., 2009) and the Project for Intercomparison of Land Surface Parameterization Schemes (PILPS) Phase 2e (Slater et al., 2001) examined the snow simulations of an ensemble of land surface schemes for the midlatitudes. However, until now there has been no attempt to evaluate the air-soil temperature relationship in the Northern Hemisphere permafrost region and the detailed role of snow depth therein across an ensemble of models. In such an investigation, a first suitable approach is the evaluation of standalone (offline) land surface models (LSMs). The retrospective (1960-2009) simulations from the model integration group of the Permafrost Carbon Network (PCN; http://www. permafrostcarbon.org) provide an opportunity to evaluate an ensemble of nine state-of-the-art LSMs. Here, the LSMs are run with observation-based atmospheric forcing, meaning that snow depth is not influenced by biases in the atmospheric forcing in a coupled model set-up. The evaluation of the offline modelled air temperature-snow depth-near-surface soil temperature relationship in winter is therefore important for revealing a model's skill in representing the effects of snow insulation.

Most of the LSMs participating in PCN are the land surface modules of Earth system models (ESMs) participating in the Coupled Model Intercomparison Project (CMIP5; http://cmip-pcmdi.llnl.gov/cmip5/) although in some cases different versions were used for PCN and CMIP5 simulations. Thus, the results we present can guide the corresponding evaluation of these ESMs, though analysis of coupled model results requires consideration of couplings between model components and is necessarily more complex.

The scope of the present study is to analyse the extent to which the ensemble of PCN models can reproduce the observed relationship between air and near-surface soil temperatures in the Northern Hemisphere permafrost region during 
winter, with a particular focus on the snow insulation effect. For the latter we analyse the impact of snow depth on the difference between near-surface soil and air temperatures. Our related key questions are the following: how well do the models represent the observed spatial pattern of the air-soil temperature difference in winter and how it is controlled by snow depth? What is the range of the simulated air-soil temperature relationship across the model ensemble? To the greatest extent possible, we try to relate the performance of the models to their snow schemes. With this aim in mind, a simultaneous analysis of simulated air and near-surface soil temperatures and snow depth is presented and compared with those from a novel data set of Russian station observations. We used this data set because it has been compiled within PCN, and it is hard to find other station data sets which provide simultaneous observations of both air and soil temperatures as well as snow depth over a long period.

In Sect. 2, we describe the model simulations, the station observations used for evaluation and the analysis methods. In Sect. 3, we present a detailed analysis of near-surface air temperature-snow depth-soil temperature relationships in winter. In Sect. 4, we discuss the roles of atmospheric forcing and model processes. In Sect. 5, we investigate the relationship between simulated snow insulation and permafrost area. We summarise our findings and present conclusions in Sect. 6.

\section{Data and analysis}

\subsection{Models}

We use data from nine LSMs participating in the PCN, including CLM4.5, CoLM, ISBA, JULES, LPJ-GUESS, MIROC-ESM, ORCHIDEE, UVic and UW-VIC. For detailed information about the models and simulations we refer to Rawlins et al. (2015), Peng et al. (2015) and McGuire et al. (2016). The total soil depth for soil thermal calculations ranges from $3 \mathrm{~m}$ (divided into 8 layers) in LPJ-GUESS to $250 \mathrm{~m}$ (divided into 14 layers) in UVic. The physical properties of the soil differ among the models as well, and four of them (CLM4.5, ISBA, UVic, UW-VIC) include organic horizons. Three models (ISBA, LPJ-GUESS, UW-VIC) do not archive soil subgrid results and provide only area-weighted ground temperature (i.e. averaged over wetlands and vegetated areas, and in some cases lake fractions).

Table 1 lists relevant snow model details. One model (UVic) uses an implicit snow scheme which replaces the upper soil column with snow-like properties, i.e. the nearsurface soil layer takes the temperature of the air-snow interface. The other models use separate snow layers on top of the ground, either a single bucket (LPJ-GUESS, UWVIC) or multilayer snow schemes (CLM4.5, CoLM, ISBA, JULES, MIROC-ESM, ORCHIDEE). Snow insulation is explicitly considered in all models: increasing snow depth in- creases the insulation effect. Most models consider the effect of varying snow density on insulation (Table 1). This is parameterised by a snow conductivity-density relationship. Some of the models (LPJ-GUESS, MIROC-ESM, ORCHIDEE, UVic) use a fixed snow density, consider only dry snow and no compaction effects, while others represent liquid water in snow and different processes for snow densification such as mechanical compaction and thermal and destructive metamorphism (Table 1).

The simulations were generally run for the period 1960 2009, although some simulations were stopped a few years earlier. Each model team was free to choose appropriate driving data sets for weather and climate, atmospheric $\mathrm{CO}_{2}$, nitrogen deposition, disturbance, land cover, soil texture, etc. However, the climate forcing data (surface pressure, surface incident longwave and shortwave radiation, near-surface air temperature, wind and specific humidity, rain and snowfall rates) are from gridded observational data sets (e.g. CRUNCEP, WATC; Table S1 in the Supplement). The exception is MIROC-ESM, which was run as a fully coupled model, forced by its own simulated climate. Mean annual air temperature simulated by MIROC-ESM for the permafrost region was within the range $\left(-7.2\right.$ to $\left.2.2^{\circ} \mathrm{C}\right)$ of the other forcing data sets used in this study and the trend in near-surface air temperature $\left(+0.03{ }^{\circ} \mathrm{C} \mathrm{yr}^{-1}\right)$ was the same for all forcing data sets. However, MIROC-ESM had both the highest annual precipitation (range 433 to $686 \mathrm{~mm}$ ) and the highest trend in annual precipitation (range -2.1 to $+0.8 \mathrm{~mm} \mathrm{yr}^{-1}$ ) among the forcing data sets.

The spatial domain of interest is the Northern Hemisphere permafrost land regions. Our analysis is based on the $0.5^{\circ} \times 0.5^{\circ}$-resolution gridded driving and modelled data for winter (DJF) 1980-2000.

\subsection{Observations}

A quality-checked data set of monthly near-surface air temperature, $20 \mathrm{~cm}$ soil temperatures and snow depth from Russian meteorological stations have been provided by the AllRussian Research Institute of Hydrometeorological Information - World Data Centre (RIHMI-WDC; http://meteo.ru/). Of the stations, 579 report snow depth and 268 provide simultaneous data on all three variables. Ground surface temperature data are not available. A detailed description of data set preparation is provided in Sherstiukov (2012a). Observing conditions at the Russian stations in all meteorological elements correspond with WMO standards. The observations presented have been included in other data sets, such as the Global Summary of the Day (GSOD) data set, HadSRUT4 etc., and are widely used in climate research (e.g. Anisimov and Sherstiukov, 2016; Decharme et al., 2016; Park et al., 2014; Brun et al., 2013; Pavlov and Malkova, 2009; PaiMazumder et al., 2008). The soil temperature data set was run through four independent methods of quality control (Sherstiukov, 2012b). However, some soil temperature 
Table 1. PCN snow model details.

\begin{tabular}{|c|c|c|c|c|c|c|}
\hline $\begin{array}{l}\text { Model reference } \\
\text { for snow scheme }\end{array}$ & $\begin{array}{l}\text { Snow } \\
\text { scheme }^{1}\end{array}$ & $\begin{array}{l}\text { Snow } \\
\text { layers }\end{array}$ & $\begin{array}{l}\text { Water } \\
\text { phases }\end{array}$ & $\begin{array}{l}\text { Liquid water } \\
\text { treatment }^{2}\end{array}$ & Snow density ${ }^{3}$ & $\begin{array}{l}\text { Snow thermal } \\
\text { conductivity }\end{array}$ \\
\hline $\begin{array}{l}\text { CLM4.5 } \\
\text { Swenson and Lawrence (2012) } \\
\text { Oleson et al. (2013) }\end{array}$ & ML & $\begin{array}{l}\text { Dynamic } \\
(\max .5)\end{array}$ & $\begin{array}{l}\text { Liquid, } \\
\text { ice }\end{array}$ & $\begin{array}{l}\text { Bucket-type } \\
\text { prognostic in } \\
\text { each layer }\end{array}$ & $\begin{array}{l}\text { depends on } \\
\text { snow depth; } \\
\text { compaction }^{3 a, b, c}\end{array}$ & $\begin{array}{l}\text { quadratic } \\
\text { equation on } \rho\end{array}$ \\
\hline $\begin{array}{l}\text { CoLM } \\
\text { Dai et al. (2003) } \\
\text { Ji et al. (2014) }\end{array}$ & ML & $\begin{array}{l}\text { Dynamic } \\
(\max .5)\end{array}$ & $\begin{array}{l}\text { Liquid, } \\
\text { ice }\end{array}$ & $\begin{array}{l}\text { Bucket-type } \\
\text { prognostic in } \\
\text { each layer }\end{array}$ & $\begin{array}{l}\text { depends on } \\
\text { snow depth; } \\
\text { compaction }^{3 a, b, c}\end{array}$ & $\begin{array}{l}\text { quadratic } \\
\text { equation on } \rho\end{array}$ \\
\hline $\begin{array}{l}\text { ISBA } \\
\text { Boone and Etchevers (2001) }\end{array}$ & ML & $\begin{array}{l}\text { Static } \\
(3)\end{array}$ & $\begin{array}{l}\text { Liquid, ice, } \\
\text { vapour }\end{array}$ & $\begin{array}{l}\text { Diagnosed from } \\
\text { snow temperature, } \\
\text { mass, density }\end{array}$ & compaction $^{3 \mathrm{a}, \mathrm{b}}$ & $\begin{array}{l}\text { quadratic equation on } \\
\rho, \text { contribution due } \\
\text { to vapour transfer }\end{array}$ \\
\hline $\begin{array}{l}\text { JULES } \\
\text { Best et al. (2011) }\end{array}$ & ML & $\begin{array}{l}\text { Dynamic } \\
(\max .3)\end{array}$ & $\begin{array}{l}\text { Liquid, ice, } \\
\text { vapour }\end{array}$ & $\begin{array}{l}\text { Bucket-type prognostic } \\
\text { in each layer }\end{array}$ & compaction $^{3 a}$ & $\begin{array}{l}\text { power equation } \\
\text { on } \rho\end{array}$ \\
\hline $\begin{array}{l}\text { LPJ-GUESS Wania et al. (2009) } \\
\text { Gerten et al. (2004) }\end{array}$ & $\mathrm{BL}$ & $\begin{array}{l}\text { Static } \\
(1)\end{array}$ & Ice & $\begin{array}{l}\text { Not } \\
\text { represented }\end{array}$ & $\begin{array}{l}\text { fixed } \\
362 \mathrm{~kg} \mathrm{~m}^{-3}\end{array}$ & $\begin{array}{l}\text { fixed } \\
0.196 \mathrm{~W} \mathrm{~m}^{-1} \mathrm{~K}^{-1}\end{array}$ \\
\hline $\begin{array}{l}\text { MIROC-ESM } \\
\text { Takata et al. (2003) }\end{array}$ & ML & $\begin{array}{l}\text { Dynamic } \\
(\max .3)\end{array}$ & Ice & $\begin{array}{l}\text { Not } \\
\text { represented }\end{array}$ & $\begin{array}{l}\text { fixed } \\
300 \mathrm{~kg} \mathrm{~m}^{-3}\end{array}$ & $\begin{array}{l}\text { fixed } \\
0.3 \mathrm{~W} \mathrm{~m}^{-1} \mathrm{~K}^{-1}\end{array}$ \\
\hline $\begin{array}{l}\text { ORCHIDEE } \\
\text { Gouttevin et al. (2012) }\end{array}$ & ML & $\begin{array}{l}\text { Dynamic } \\
(\max .7)\end{array}$ & Ice & $\begin{array}{l}\text { Not } \\
\text { represented }\end{array}$ & $\begin{array}{l}\text { fixed } \\
330 \mathrm{~kg} \mathrm{~m}^{-3}\end{array}$ & $\begin{array}{l}\text { fixed } \\
0.25 \mathrm{~W} \mathrm{~m}^{-1} \mathrm{~K}^{-1} \\
\text { for tundra, } \\
0.042 \mathrm{~W} \mathrm{~m}^{-1} \mathrm{~K}^{-1} \\
\text { for taiga }\end{array}$ \\
\hline $\begin{array}{l}\text { UVic } \\
\text { Meissner et al. (2003) } \\
\text { Avis (2012) }\end{array}$ & I & $\begin{array}{l}\text { Static } \\
\text { (1) }\end{array}$ & Ice & $\begin{array}{l}\text { Not } \\
\text { represented }\end{array}$ & $\begin{array}{l}\text { fixed } \\
330 \mathrm{~kg} \mathrm{~m}^{-3}\end{array}$ & $\begin{array}{l}\text { bulk } \\
\text { conductivity }\end{array}$ \\
\hline $\begin{array}{l}\text { UW-VIC } \\
\text { Andreadis et al. (2009) }\end{array}$ & $\mathrm{BL}$ & $\begin{array}{l}\text { Dynamic } \\
(\max .2)\end{array}$ & $\begin{array}{l}\text { Liquid, ice, } \\
\text { vapour }\end{array}$ & $\begin{array}{l}\text { Constant liquid } \\
\text { water holding capacity }\end{array}$ & compaction $^{3 a, b}$ & $\begin{array}{l}\text { fixed } \\
0.7 \mathrm{Wm}^{-1} \mathrm{~K}^{-1}\end{array}$ \\
\hline
\end{tabular}

observations could be disturbed by grass cutting during the warm season and the removal of organic materials, mainly at agricultural sites, which may affect the trend in the warm season (Park et al., 2014), but this does not affect our results on the air-upper soil temperature relationship in winter.

Precipitation station data have been compiled from the GSOD data set produced by the National Climatic Data Center (NCDC; http://www.ncdc.noaa.gov) for all of the stations that are included in the RIHMI-WDC data set. In addition to the station's ground snow depth observations we use gridded snow water equivalent (SWE) data from the GlobSnow-2 product (http://www.globsnow.info/swe/), which have been produced using a combination of passive microwave radiometer and ground-based weather station data (Takala et al., 2011). Orographic complexity, vegetation cover and snow state (e.g. wet snow) affect the accuracy of this product. When compared with ground measurements in Eurasia, the GlobSnow product shows root mean square error (RMSE) values of 30 to $40 \mathrm{~mm}$ for SWE values below $150 \mathrm{~mm}$, with retrieval uncertainty increases when SWE is above this threshold (e.g. Takala et al., 2011; Muskett, 2012; Klehemet et al., 2013). In order to be compared with station data, snow depth was then calculated from SWE using a snow density of $250 \mathrm{~kg} \mathrm{~m}^{-3}$, which is a median observed value in winter. Zhong et al. (2014) report snow density values of 180 $250 \mathrm{~kg} \mathrm{~m}^{-3}$ for tundra/taiga and $156-193 \mathrm{~kg} \mathrm{~m}^{-3}$ for alpine snow classes. Woo et al. (1983) report snow density values of $250-400 \mathrm{~kg} \mathrm{~m}^{-3}$ for various terrain types. Choice of density does not materially affect the results.

All these data have been compiled for winter (DJF) and the same time period of 1980-2000. This period was chosen because soil temperature data are sparse before 1980 and the JULES simulation stopped in the year 2000. Comparison of the simulations with the station data was done using a weighted bilinear interpolation from the four surrounding model grid points onto the station locations.

\subsection{Analysis methods}

Our analysis is focused on the common winter (DJF) condition, although snow can begin in November or even earlier and end at the beginning of May, but we checked that a different winter definition (NDJFMA) does not qualita- 
tively change any of the intervariable relationships found. The focus in our study is on the evaluation of the simulated air-soil temperature relationships, modulated by snow depth. For this, we analyse the winter mean as well as the interannual variability (expressed as the standard deviation) of four key variables: near-surface air temperature $\left(T_{\text {air }}\right)$, nearsurface soil temperature (soil temperature at $20 \mathrm{~cm}$ depth; $\left.T_{\text {soil }}\right)$, snow depth $\left(d_{\text {snow }}\right)$ and the difference between $T_{\text {soil }}$ and $T_{\text {air. }}$. This difference $\Delta T\left(\Delta T=T_{\text {soil }}-T_{\text {air }}\right)$ is called the air-soil temperature difference. By limiting our analysis to winter only, we are able to attribute the cross-model and model-to-observation differences in $\Delta T$ primarily to snow insulation effects. In winter, the effects of other factors (e.g. soil moisture, texture) on $\Delta T$ are much smaller than that of snow. Ground surface temperatures were not recorded in the Russian data set, but $20 \mathrm{~cm}$ soil depth temperatures were. To test how sensitive results are using $20 \mathrm{~cm}$ depth temperatures instead of ground surface temperatures, we also analysed model-simulated temperature differences between ground surface and $T_{\text {air }}$, and found no qualitative differences, hence justifying the use of $20 \mathrm{~cm}$ observations.

We use the Pearson product-moment correlation coefficient and its significance (von Storch and Zwiers, 1999) to investigate the covariability between $\Delta T$ and $d_{\text {snow }}$ as well as between $T_{\text {soil }}$ and its two forcing factors ( $T_{\text {air }}$ and $\left.d_{\text {snow }}\right)$. Before we compute the correlations, we detrended the data by removing a least squares regression line. The calculated correlation maps (i.e. spatial distributions of correlation coefficients) based on model and observation data, allow comparison of the spatial patterns of these relationships.

To further examine the functional behaviour between the key variables, we present relation diagrams between pairs of variables (e.g. variation of $\Delta T$ with change of $d_{\text {snow }}$ ). To evaluate the performance of the individual LSMs we calculate the RMSE between the observed and modelled relationships. We illustrate the dependence of $\Delta T$ vs. $d_{\text {snow }}$ and $T_{\text {soil }}$ vs. $d_{\text {snow }}$ relations for three $T_{\text {air }}$ ranges. To distinguish dry snow pack regimes from those where sporadic melt may occur even in winter, we split $T_{\text {air }}$ into three regimes: the coldest conditions $\left(T_{\text {air }} \leq-25^{\circ} \mathrm{C}\right.$, representing $24 \%$ of observations), the intermediate temperature conditions $\left(-25^{\circ} \mathrm{C}<T_{\text {air }} \leq-15^{\circ} \mathrm{C}\right.$, representing $42 \%$ of the observations), and the warmest conditions $\left(-15^{\circ} \mathrm{C}<T_{\text {air }} \leq-5^{\circ} \mathrm{C}\right.$, representing $34 \%$ of observations). Hence it is an indirect separation of temperature-gradient metamorphosis regimes and density-gradient metamorphosis snow pack regimes. Additionally, we present conditional probability density functions (PDFs) of $\Delta T$ for different snow depth and air temperature regimes and compare the simulated PDFs with those obtained from station observations.
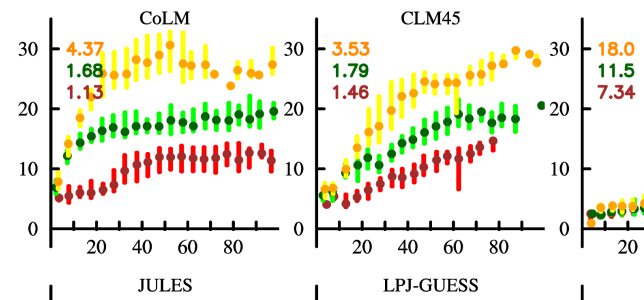

ISBA
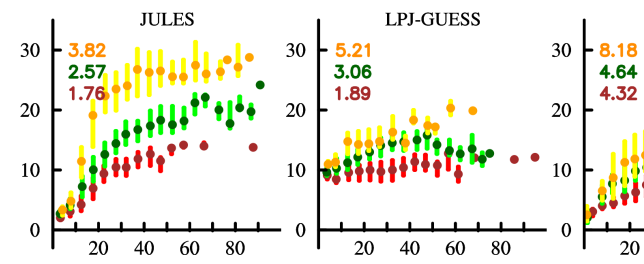

4.64
4.32

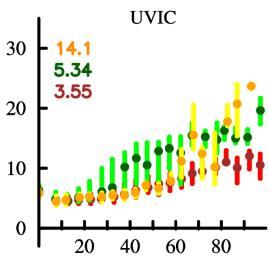

UW-VIC

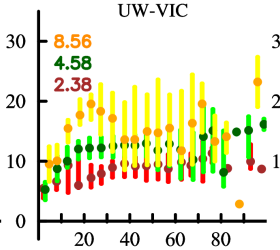

MIROC-ESM
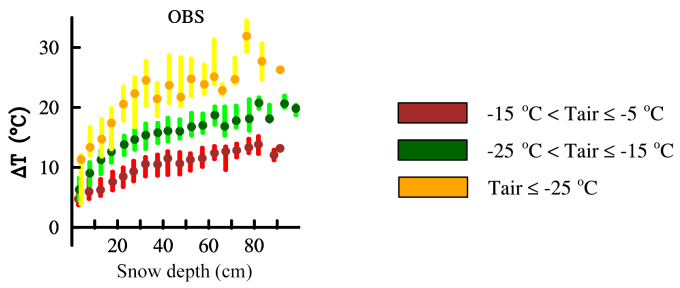

Figure 1. Variation of $\Delta T\left({ }^{\circ} \mathrm{C}\right)$, the difference between soil temperature at $20 \mathrm{~cm}$ depth and air temperature with snow depth $(\mathrm{cm})$ for winter 1980-2000. The dots represent the medians of $5 \mathrm{~cm}$ snow depth bins and the upper and lower bars indicate the 25th and 75th percentiles, calculated from all Russian station grid points $(n=268)$ and 21 individual winters. The numbers in each model panel indicate the RMSE between the observed and modelled relationship. Colours represent different air temperature regimes.

\section{Results}

\subsection{Relationship between air-soil temperature difference and snow depth}

The relationship between air-soil temperature difference $(\Delta T)$ and snow depth $\left(d_{\text {snow }}\right)$ in winter (Fig. 1) shows an increase of $\Delta T$ with increasing $d_{\text {snow }}$ in the Russian station observations. The data exhibit a linear relation between $\Delta T$ and $d_{\text {snow }}$ at relatively shallow snow depths with a trend towards asymptotic behaviour at thicker snow, which is in agreement with earlier findings (Zhang, 2005; Ge and Gong, 2010; Morse et al., 2011). There is also significant scatter in the observation-based relationship indicated by the interquartile range in $\Delta T$ of $1.5-8.5^{\circ} \mathrm{C}$ at specific snow depth and air temperature regimes, likely resulting from complicating factors such as snow pack density and moisture content variability over the winter, as well as observational errors. 
(a)
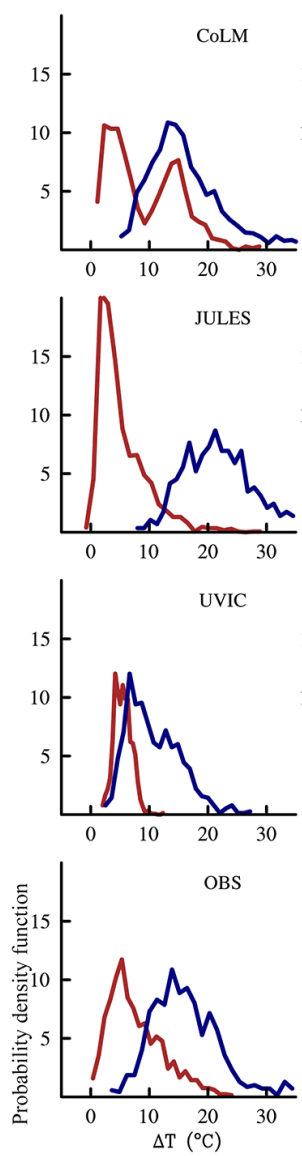

(b)
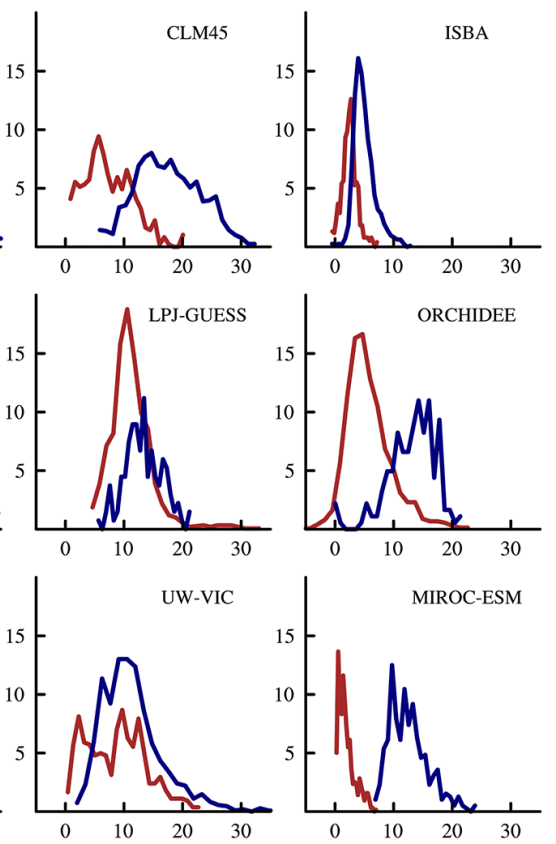
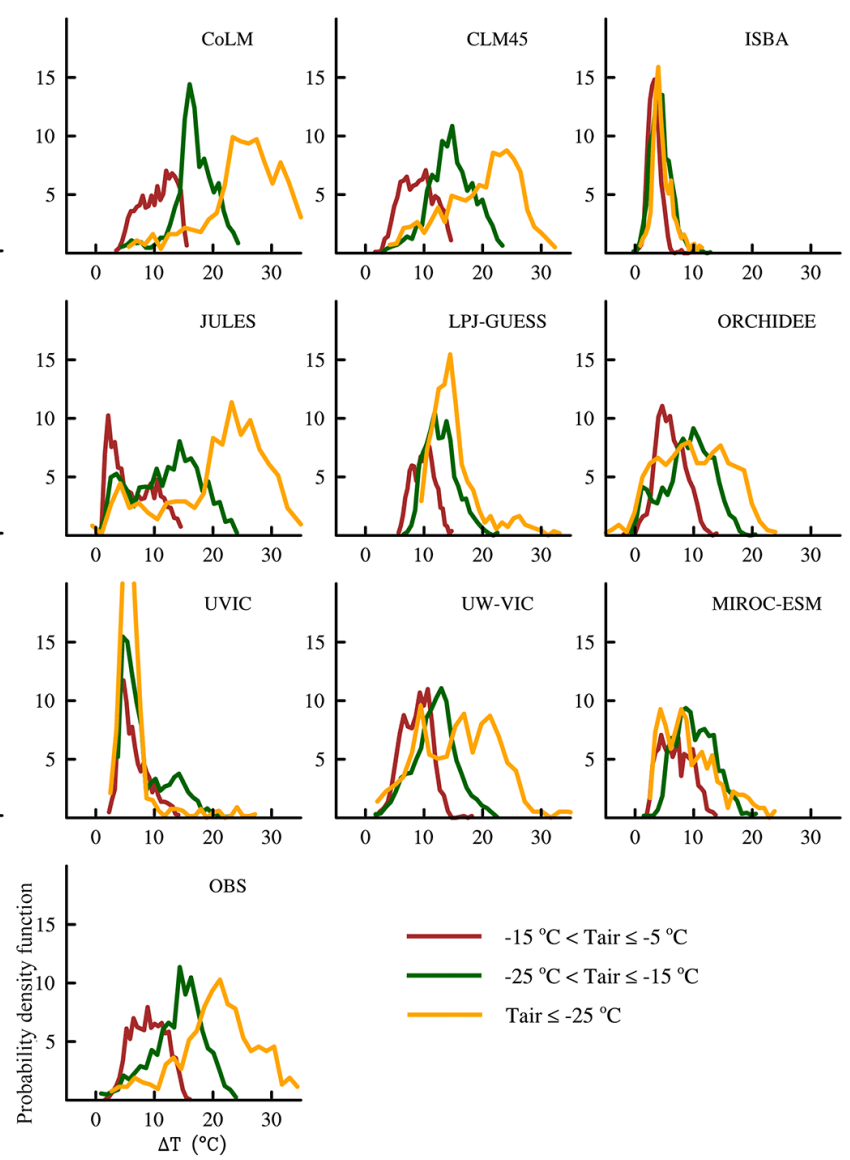

Figure 2. Conditional probability density functions (PDFs) of $\Delta T\left({ }^{\circ} \mathrm{C}\right)$, the difference between soil temperature at $20 \mathrm{~cm}$ depth and air temperature for (a) different snow depth classes and (b) air temperature regimes for winter 1980-2000.

All models reproduce the observed relationship, i.e. increasing $\Delta T$ with increasing $d_{\text {snow }}$. However, Fig. 1 also shows a wide cross-model spread in the simulated relationships and shows that some of the models are not consistent with the behaviour in the observations. Only three models (CLM4.5, CoLM, JULES) reproduce the observed $\Delta T$ vs. $d_{\text {snow }}$ relationship reasonably well using a benchmark of RMSE $<5^{\circ} \mathrm{C}$ for all temperature regimes. In particular LPJGUESS, ORCHIDEE, UVic, UW-VIC, MIROC-ESM show large RMSE for cold air conditions. ISBA stands out overall, with a RMSE of $7-18^{\circ} \mathrm{C}$ in all temperature ranges. We conclude that these models do not adequately represent the features of the observed $\Delta T$ vs. $d_{\text {snow }}$ relationship. The scatter in the modelled relationships, indicated by the interquartile range, is of the same order as in the observations, except for ISBA and MIROC-ESM, which produce noticeably smaller variations.

Figure 2a views the $\Delta T$ vs. $d_{\text {snow }}$ relationship in a complementary form using the PDFs of $\Delta T$ for different snow depth regimes. This analysis allows for a detailed evaluation of the snow-regime-dependent $\Delta T$ separation by quantify- ing and comparing the modal value and width of the different conditional PDFs. Since the Russian snow depths are clearly non-normal in distribution (Fig. S1 in the Supplement, with a median $d_{\text {snow }}$ of $30 \mathrm{~cm}$ ), we divide the data into "shallow" $\left(d_{\text {snow }} \leq 20 \mathrm{~cm}\right)$ and "thick" $\left(d_{\text {snow }} \geq 45 \mathrm{~cm}\right)$ regimes to separate two snow depth regimes. The modal value of the station-based $\Delta T$ PDF is $5{ }^{\circ} \mathrm{C}$ for shallow snow and $14{ }^{\circ} \mathrm{C}$ for thick snow; that is, thick snow is a better insulator than thin snow. Based on the $\Delta T$ PDFs, five models (CoLM, CLM4.5, JULES, ORCHIDEE, MIROC-ESM) successfully separate the $\Delta T$ regimes under different snow depth conditions. Their simulated $\Delta T$ PDFs have a smaller modal value for thin snow than for thick snow, like in the observations. The other models clearly fail in separating the $\Delta T$ PDFs for the two different snow depth regimes. However, even for the five successful models, both the shapes and the modal values of the simulated PDFs differ from the observed PDF.

Both Figs. 1 and $2 \mathrm{~b}$ further indicate that $\Delta T$ is related to $T_{\text {air }}$ conditions. This is expected due to the effects of $T_{\text {air }}$ on snow pack properties, particularly its density and moisture content that affect the thermal conductivity of the snow. For 

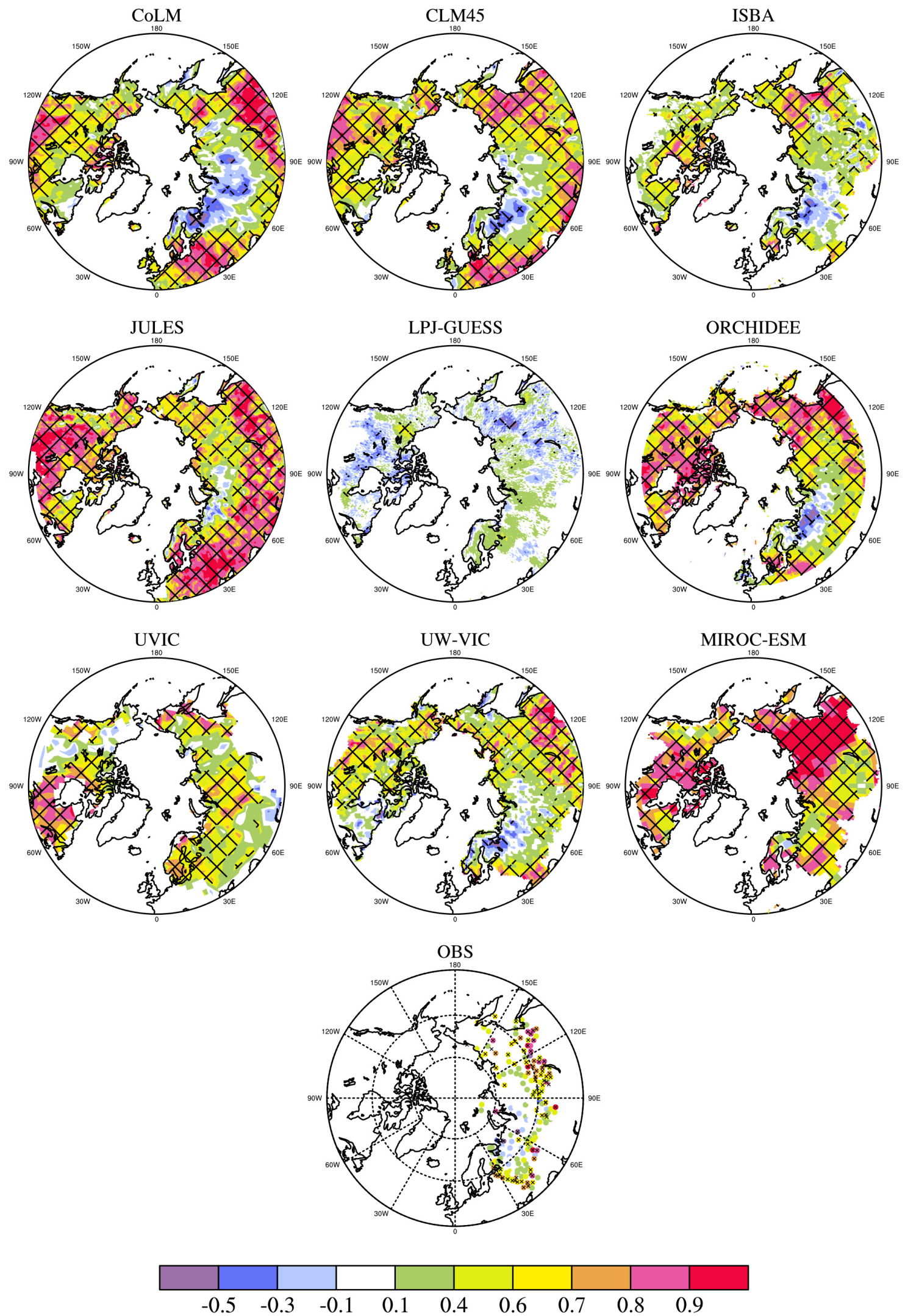

Figure 3. Spatial maps of the correlation coefficients between snow depth and $\Delta T$, the difference between soil temperature at $20 \mathrm{~cm}$ depth and air temperature for winter 1980-2000. Regions with greater than $95 \%$ significance are hashed. 
example, the density of fresh fallen snow tends to be much lower under cold $T_{\text {air }}$ than warm (Anderson, 1976), leading to increased insulation (larger $\Delta T$ ). Snow densification is also a function of $T_{\text {air }}$; for example, depth hoar metamorphosis of the snow pack, which produces more insulation (loosely packed depth-hoar crystals have very low thermal conductivity), is promoted by strong thermal gradients in the snow pack and is typical of continental climates (e.g. Zhang et al., 1996). Therefore, we can expect that the same thickness of snow in colder climates will provide greater insulation than it would in warmer climates.

Our analysis of observations (Figs. 1 and $2 \mathrm{~b}$ ) confirms (i) a larger $\Delta T$ for colder $T_{\text {air }}$ than for warmer $T_{\text {air }}$ (for a given snow depth), (ii) a greater sensitivity of $\Delta T$ to changes in $d_{\text {snow }}$ in colder $T_{\text {air }}$ (Fig. 1) and (iii) a larger modal value of the $\Delta T$ PDF for colder $T_{\text {air }}$ than for warmer $T_{\text {air }}$ $\left(21^{\circ} \mathrm{C}\right.$ for $T_{\text {air }} \leq-25^{\circ} \mathrm{C}$ and $9{ }^{\circ} \mathrm{C}$ for $-15^{\circ} \mathrm{C}<T_{\text {air }} \leq-5^{\circ} \mathrm{C}$; Fig. 2b). These effects are consistent with colder climates having lower density snow packs, and the differences are in line with measurements of snow density variability (Zhong et al., 2014). Additionally, both the interquartile range in Fig. 1 and the width of the PDFs in Fig. $2 \mathrm{~b}$ become larger as $T_{\text {air }}$ cool. This may be related to the formation of depth hoar, which is a very good insulator and its varying presence in the snow pack decouples $\Delta T$ from $d_{\text {snow }}$. Cold, thin snow packs tend to contain much more low-density depth hoar than warmer snow packs (e.g. Zhang et al., 1996; Singh et al., 2011). Continental regions have large annual temperature cycles, with greater interannual variability and thinner snow packs than maritime ones. This variability leads to greater scatter and greater sensitivity of the $\Delta T$ vs. $d_{\text {snow }}$ relationship in the cold winter regions. An additional cause of scatter is that the density of fresh-fallen snow decreases with the decrease of temperature. Accordingly, in the cold $T_{\text {air }}$ regime $\left(T_{\text {air }} \leq-25^{\circ} \mathrm{C}\right)$ we find a larger $\Delta T$ in early winter (November-December), when the snow pack is composed of thinner lower-density fresh snow (and depth hoar), than late winter (January-February; Fig. S2). Under warm conditions $\left(-15^{\circ} \mathrm{C}<T_{\text {air }} \leq-5^{\circ} \mathrm{C}\right)$ such a separation is not observed.

If we evaluate the models with respect to this observed impact of $T_{\text {air }}$ on the $\Delta T$ vs. $d_{\text {snow }}$ relationship, we demonstrate that some models (CLM4.5, CoLM, JULES) are better able to replicate the effect than others (LPJ-GUESS, MIROCESM, ORCHIDEE, UW-VIC; Fig. 1). The latter do not fully replicate the larger $\Delta T$ under cold $T_{\text {air }}$ conditions. CLM4.5, CoLM and JULES capture a larger $\Delta T$ for colder $T_{\text {air }}$ for a given $d_{\text {snow }}$ in agreement with the observations. However, for shallow snow, JULES simulates an increase of $\Delta T$ with increasing $d_{\text {snow }}$ for all temperature ranges that is twice as large as observations. Two models (ISBA, UVic) clearly fail in this evaluation. Poor model performance in reflecting $T_{\text {air }}$ influence on the $\Delta T$ vs. $d_{\text {snow }}$ also manifests itself in regime separation of the PDFs (Fig. 2b). Some models do not separate the $\Delta T$ regimes under different $T_{\text {air }}$ conditions well or at all (ISBA, LPJ-GUESS, MIROC-ESM, UVic), while others
Table 2. Sensitivity of near-surface soil temperature $\left(T_{\text {soil }}\right)$ to air temperature $\left(T_{\text {air }}\right)$ in winter (DJF) calculated by the slopes of the linear regression between $T_{\text {soil }}\left({ }^{\circ} \mathrm{C}\right)$ and $T_{\text {air }}\left({ }^{\circ} \mathrm{C}\right)$ for different regimes of snow depth $\left(d_{\text {snow }}\right)$, using data from all Russian station grid points and 21 individual winter 1980-2000. All relationships are statistically significant at $p \leq 0.01$.

\begin{tabular}{lcccc}
\hline & \multicolumn{4}{c}{ Snow depth regimes } \\
\cline { 2 - 6 } & \multicolumn{2}{c}{ Shallow } & \multicolumn{2}{c}{ Thick } \\
& \multicolumn{2}{c}{$d_{\text {snow }} \leq 20 \mathrm{~cm}$} & \multicolumn{2}{c}{$d_{\text {snow }} \geq 45 \mathrm{~cm}$} \\
\cline { 2 - 5 } & $T_{\text {soil }}$ vs. $T_{\text {air }}$ & $R^{2}$ & $T_{\text {soil }}$ vs. $T_{\text {air }}$ & $R^{2}$ \\
& $\left({ }^{\circ} \mathrm{C}^{\circ} \mathrm{C}^{-1}\right)$ & & $\left(\mathrm{C}^{\circ} \mathrm{C}^{-1}\right)$ & \\
\hline Observation & 0.62 & 0.79 & 0.21 & 0.41 \\
CLM4.5 & 0.69 & 0.89 & 0.33 & 0.56 \\
CoLM & 0.49 & 0.73 & 0.13 & 0.44 \\
ISBA & 0.93 & 0.98 & 0.93 & 0.94 \\
JULES & 0.68 & 0.77 & 0.19 & 0.46 \\
LPJ-GUESS & 0.73 & 0.89 & 0.52 & 0.75 \\
MIROC-ESM & 0.78 & 0.98 & 0.49 & 0.67 \\
ORCHIDEE & 0.86 & 0.83 & 0.56 & 0.64 \\
UVic & 0.96 & 0.97 & 0.81 & 0.68 \\
UW-VIC & 0.54 & 0.74 & 0.76 & 0.65 \\
\hline
\end{tabular}

cannot capture the observed cold temperature regime features (i.e. too broad PDFs and shifts towards smaller modal values; ORCHIDEE, UW-VIC). The three models with reasonable intervariable relations (CLM4.5, CoLM, JULES) also capture the regime separation in the PDFs. These three models, as well as LPJ-GUESS and ORCHIDEE, also represent the observed greater insulation of early winter snow packs under cold conditions (Fig. S2).

The maps of the $\Delta T$ vs. $d_{\text {snow }}$ correlations in winter (Fig. 3) demonstrate a pronounced spatial variability in the $\Delta T$ vs. $d_{\text {snow }}$ relationship. The highest positive correlation occurs in the region of eastern Siberia and the Siberian Highlands. In other regions, namely Scandinavia, the western Russian Arctic, West Siberian Plain and Central Siberian Plateau, the correlation is much weaker and often not statistically significant. These regions have snow (Sect. 4.1.2) influenced by North Atlantic cyclonic activity which brings relatively warm moist air and heavy precipitation in winter (and a positive correlation between $d_{\text {snow }}$ and $T_{\text {air }}$ ), leading to relatively small mean $\Delta T$.

Some models (CLM4.5, CoLM, ORCHIDEE, UW-VIC) show a reasonable spatial pattern of correlation coefficient $(r \geq 0.4)$ compared to those of the observations, while the others do not (Fig. 3). Obvious outliers are the LPJ-GUESS and UVic models, which do not reproduce the observed pattern of correlation. UVic calculates a reverse spatial pattern comparing to that of the observations (e.g. significant positive correlation in West Siberian Plain and Central Siberian Highlands). LPJ-GUESS produces very few statistically significant correlations. 

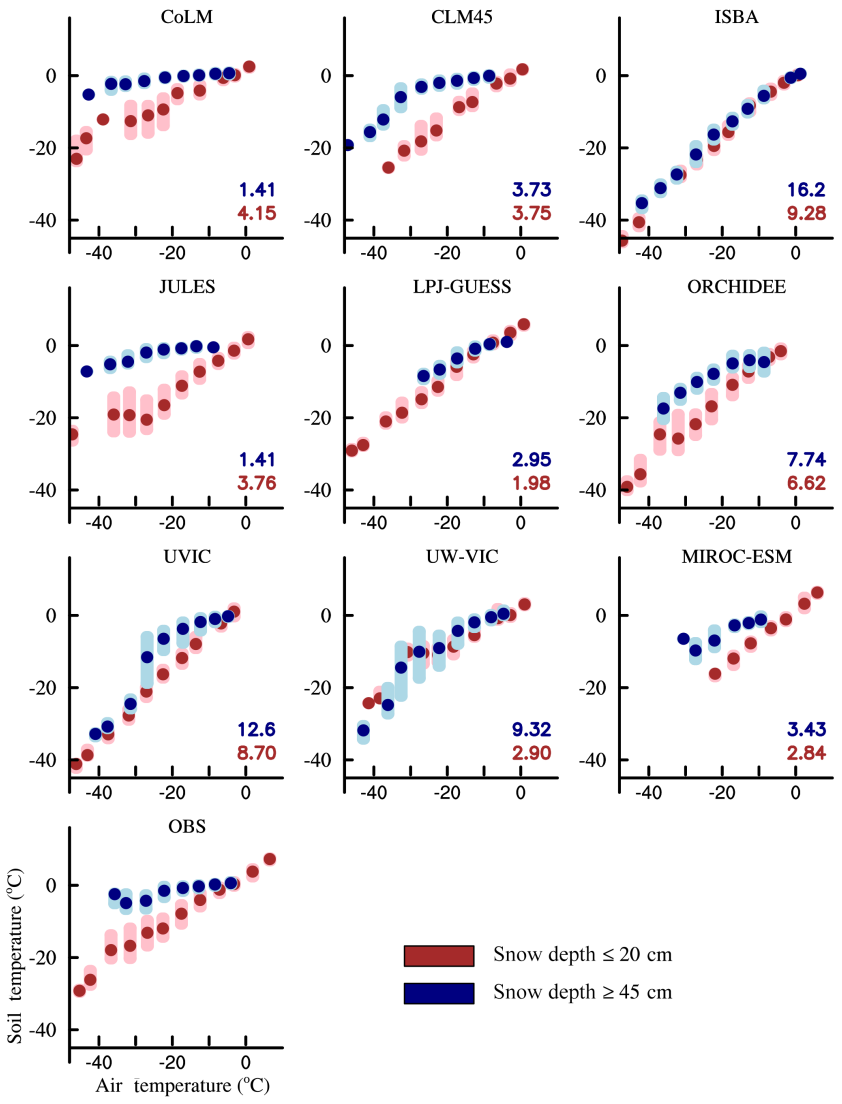

Figure 4. Variation of soil temperature at $20 \mathrm{~cm}$ depth $\left({ }^{\circ} \mathrm{C}\right)$ with air temperature $\left({ }^{\circ} \mathrm{C}\right)$ for winter $1980-2000$. The dots represent the medians of $5{ }^{\circ} \mathrm{C}$ air temperature bins and the upper and lower bars indicate the 25 th and 75 th percentiles, calculated from all Russian station grid points $(n=268)$ and 21 individual winters. The numbers in each model panel indicate the RMSE between the observed and modelled relationship. Colours represent different snow depth regimes.

\subsection{Variability of soil temperature with air temperature and snow depth}

Next we assess whether or not the models can correctly reproduce the interannual near-surface soil temperature $\left(T_{\text {soil }}\right)$ variability in relation to snow depth $\left(d_{\text {snow }}\right)$ and near-surface air temperature $\left(T_{\text {air }}\right)$ variability. Previous studies have noted that the strength of the relationship between $T_{\text {soil }}$ and $T_{\text {air }}$ is modulated by $d_{\text {snow }}$ and the snow insulation effect increases only up to a limiting depth beyond which extra snow makes little difference to soil temperatures (Smith and Riseborough, 2002; Sokratov and Barry, 2002; Zhang, 2005; Lawrence and Slater, 2010). Zhang (2005) reported that the limiting snow depth is approximately $40 \mathrm{~cm}$.

To inspect the difference in insulation capacity for shallow and thick snow, we investigate the $T_{\text {soil }}$ vs. $T_{\text {air }}$ relationship under shallow $\left(d_{\text {snow }} \leq 20 \mathrm{~cm}\right)$ and thick $\left(d_{\text {snow }} \geq 45 \mathrm{~cm}\right)$ snow conditions. Our Russian observation analysis (Fig. 4,
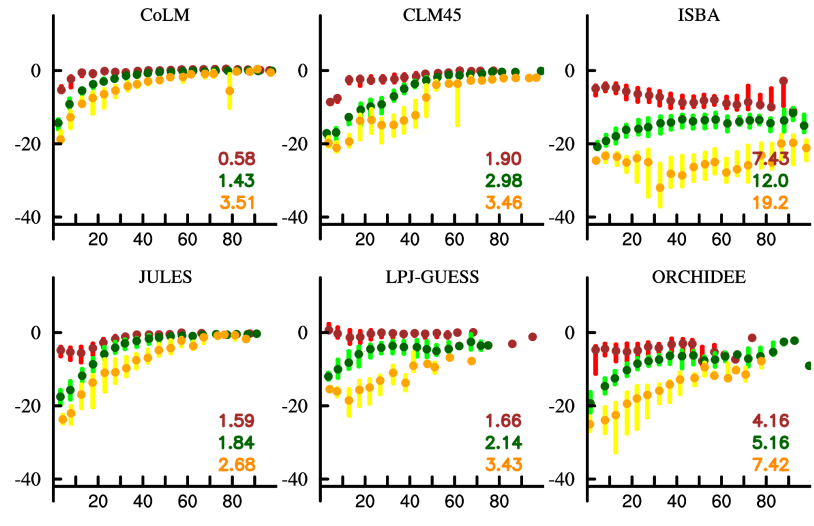

ORCHIDEE
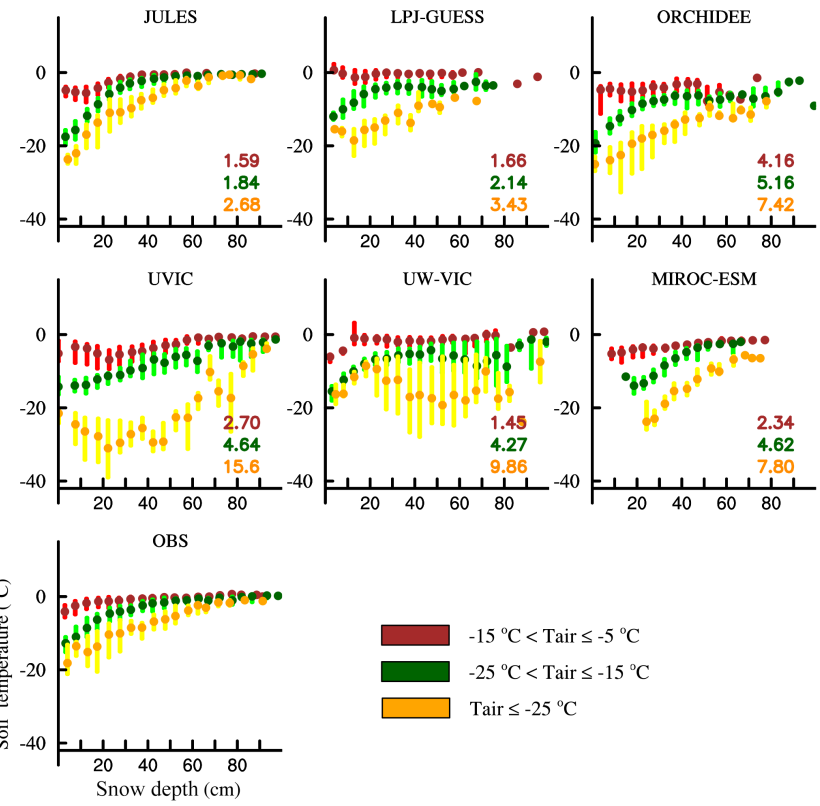

Figure 5. Variation of soil temperature at $20 \mathrm{~cm}$ depth $\left({ }^{\circ} \mathrm{C} ; y\right.$ axis) with snow depth $(\mathrm{cm})$ for winter 1980-2000. The dots represent the medians of $5 \mathrm{~cm}$ snow depth bins and the upper and lower bars indicate the 25th and 75th percentiles, calculated from all Russian station grid points $(n=268)$ and 21 individual winters. The numbers in each model panel indicate the RMSE between the observed and modelled relationship. Colours represent different air temperature regimes.

Table 2) indicate a regression slope between $T_{\text {soil }}$ and $T_{\text {air }}$ $\left(0.62{ }^{\circ} \mathrm{C}^{\circ} \mathrm{C}^{-1}, R^{2}=0.8\right)$ that is 3 times higher under shallow snow pack than thicker snow conditions $\left(0.21^{\circ} \mathrm{C}^{\circ} \mathrm{C}^{-1}\right.$, $\left.R^{2}=0.4\right)$. This is consistent with observations that the mean freezing $\mathrm{n}$-factor (the ratio of freezing degree days at the ground surface to air freezing degree days) is high at sites where the snow cover is thin or absent and low at sites where the snow cover is thick (e.g. for Yukon in Canada; Karunaratne and Burn, 2003).

Figure 4 clearly shows that some models (CoLM, CLM45, JULES) can capture this difference well. Their regression slopes for thick and thin snow are well separated and in agreement with those from the observed relationship (Table 2). The RMSE of their modelled $T_{\text {soil }}$ vs. $T_{\text {air }}$ relationships from observations is smaller than $4^{\circ} \mathrm{C}$. These models better reproduce the observed $\Delta T$ vs. $d_{\text {snow }}$ relationship. Other models (LPJ-GUESS, MIROC-ESM, ORCHIDEE) do not reproduce the much greater regression slope between $T_{\text {soil }}$ and $T_{\text {air }}$ for shallow snow than for thick snow as the 
observations show. They also produce a regression slope for thick snow which is more than twice as large as for the observations. Two models (ISBA, UVic) do not show any sensitivity in the $T_{\text {soil }}$ vs. $T_{\text {air }}$ relation to snow conditions (Fig.4, Table 2). Another measure quantitatively confirms the same models behaviour: the observed average $d_{\text {snow }}$ in the shallow snow regime is $13.7 \mathrm{~cm}$ and that for the thick snow regime is $58.5 \mathrm{~cm}$, so we would expect, if near-surface $T_{\text {air }}$ and conductivities were equal in both snow depth classes, that a ratio between the slopes for shallow and thick snow would be 4.3. CLM4.5, CoLM and JULES reproduce this observed variation in the $T_{\text {soil }}$ vs. $T_{\text {air }}$ relation better than others (Table 2). JULES and CoLM indicate a change of a factor of 4, while CLM4.5 indicates a change of factor of 2. Other models (LPJ-GUESS, MIROC-ESM, ORCHIDEE) underestimate the increase of the regression slope for decreasing snow depth; they simulate only a factor change of about 1.5. The two models with unrealistic $\Delta T$ vs. $d_{\text {snow }}$ relationships (ISBA, UVic) also fail in this evaluation of their $T_{\text {soil }}$ vs. $T_{\text {air }}$ relationship. They simulate a too-strong sensitivity of $T_{\text {soil }}$ to $T_{\text {air }}$ (regression slopes larger than $0.9^{\circ} \mathrm{C}^{\circ} \mathrm{C}^{-1}, R^{2}>0.7$; Table 2) that is almost completely independent of the snow depth regimes, particularly in ISBA, which is not consistent with observations. These models' spatial correlation patterns between $T_{\text {soil }}$ and $T_{\text {air }}$ also differ greatly from the observations and the other models (Fig. S3) and show very high positive correlation $(r>0.8)$ in most regions, as may be expected from the large regression slope shown in Fig. 4. The RMSE of their modelled $T_{\text {soil }}$ vs. $T_{\text {air }}$ relationships from observations reaches ca. $10^{\circ} \mathrm{C}$.

The $T_{\text {soil }}$ vs. $d_{\text {snow }}$ relationship (Fig. 5) displays the variation of $T_{\text {soil }}$ with changing snow depth and emphasises the reduced sensitivity of $T_{\text {soil }}$ to snow depth under thick snow conditions. With increasing $d_{\text {snow }}, T_{\text {soil }}$ asymptotically converges towards a value of around $0{ }^{\circ} \mathrm{C}$. Overall, the Russian observations indicate that snow depth above about $80-90 \mathrm{~cm}$ has very little additional insulation effect on $T_{\text {soil }}$. Most models show consistent results with regard to this aspect, although the interquartile range of $T_{\text {soil }}$ for specific snow depths is quite large in some models (ISBA, ORCHIDEE, UVic, UWVIC; Fig. 5). The figure further points to the air temperature dependency of the relation. On average, for a given $d_{\text {snow }}$, a colder $T_{\text {soil }}$ is observed for colder near-surface air temperatures, compared with warmer air temperatures. Most models can replicate this effect of air temperature on the $T_{\text {soil }}$ vs. $d_{\text {snow }}$ relationship, though with differing accuracy. The RMSE between the observed and modelled relationships can reach ca. $10^{\circ} \mathrm{C}$ or more (in ISBA, UVic, UW-VIC), particularly under cold conditions.

The spatial patterns of the correlation coefficients between $T_{\text {soil }}$ and $T_{\text {air }}$ (Fig. S3) and between $T_{\text {soil }}$ and $d_{\text {snow }}$ (Fig. S4) show a relatively large cross-model scatter in many regions. Obvious outliers in the $T_{\text {soil }}$ vs. $T_{\text {air }}$ correlation maps are ISBA and UVic, which strongly overestimate the correlation $(r>0.9)$ over most of the Arctic. This indicates an underes- timated snow insulation effect and confirms the weak insulation in both models, which we already discussed based on their underestimated $\Delta T$ (Fig. 1) and weak correlation between $\Delta T$ and $d_{\text {snow }}$ (Fig. 3). Other models (LPJ-GUESS, ORCHIDEE, UW-VIC) also overestimate the correlation in some regions (e.g. western Russian Arctic, $r>0.7$ ). Most of the simulated maps of $T_{\text {soil }}$ vs. $d_{\text {snow }}$ correlation agree with the observations on a strong positive correlation in eastern Siberia. This is a region of relatively shallow snow (10$40 \mathrm{~cm}$; Fig. 6) and there $T_{\text {soil }}$ is very sensitive to variations in snow depth (e.g. Romanovsky et al., 2007). Comparing both simulated correlation maps, it is obvious that in this region, $T_{\text {soil }}$ correlates more strongly with $d_{\text {snow }}$ than with $T_{\text {air }}$, in agreement with the Russian data and earlier studies (Romanovsky et al., 2007; Sherstyukov, 2009).

\section{Roles of atmospheric forcing and model processes}

The cross-model differences in the snow insulation effect, presented by the air temperature-snow depth-soil temperature relationships described above, are partially due to the differences in the atmospheric forcing data and also due to differences in the snow and soil physics used in the LSMs. However, because the climate forcing data sets utilised with each model are observation-based (except for MIROC-ESM), obvious outliers in individual model performance likely indicate poor or deficient physical descriptions of the air-snow-soil relations in that specific LSM.

\subsection{Atmospheric forcing and snow depth}

\subsubsection{Air temperature and precipitation}

Both near-surface air temperature $\left(T_{\text {air }}\right)$ and precipitation are given by the climate forcing data sets (Table S1) for all models, except for MIROC-ESM, which simulates both. The cross-model differences in forcing $T_{\text {air }}$ are relatively small and the simulated spatial patterns of temperature are very similar (Fig. S5). All forcing data sets are somewhat colder than Russian station data in their grid cells. The biases of winter mean $T_{\text {air }}$ range from -0.8 to $-4.7^{\circ} \mathrm{C}$ (Table S2), reflecting biases in the climate forcing data used by the models. In contrast, MIROC-ESM has a positive (mean) $T_{\text {air }}$ bias of $+2.7^{\circ} \mathrm{C}$.

The large-scale patterns of precipitation are similar across the models, but regional differences can be large (Fig. S6). The individual differences in winter precipitation range from -0.2 to $+0.5 \mathrm{~mm} \mathrm{day}^{-1}$ (Table S2) relative to the average of the Russian station data. Unfortunately, snowfall was archived in only a few models; however large-scale spatial patterns are similar across these models (Fig. S7). 

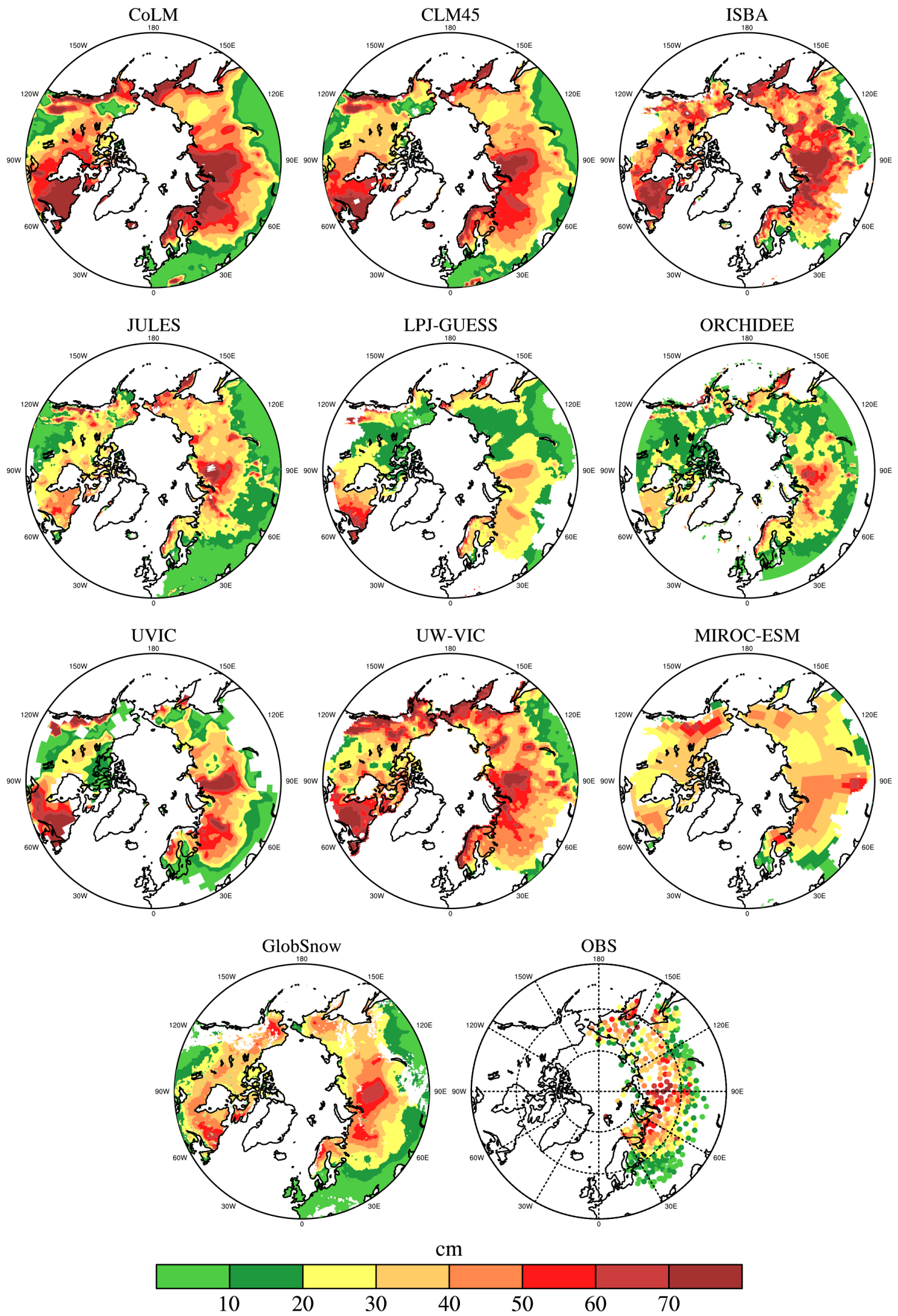

Figure 6. Spatial maps of snow depth (cm) for winter 1980-2000. 
Table 3. Russian station location averaged error statistics for snow depth $(\mathrm{cm})$ and temperature difference between $20 \mathrm{~cm}$ soil and air temperature $\left(\Delta T ;{ }^{\circ} \mathrm{C}\right)$ for winter $1980-2000$. For each variable, the maximum available number of observations $(n)$ is used. Mean ${ }^{\text {St,GS }}$ and STD $^{\text {St,GS }}$ are the observed mean and interannual variability (standard deviation), while STD is the standard deviations of each model. Bias is the mean error "simulation minus observation" and RMSE is the root mean square error. The statistics for snow depth are given based on both station observation (St) and GlobSnow (GS) data.

\begin{tabular}{|c|c|c|c|c|c|c|c|c|}
\hline & \multicolumn{5}{|c|}{ Snow depth $(n=579)$} & \multicolumn{3}{|c|}{$\Delta T(n=268)$} \\
\hline & \multicolumn{5}{|c|}{$\begin{array}{c}\text { mean }^{\mathrm{St}}=26.4 \mathrm{~cm}, \text { mean }^{\mathrm{GS}}=23.4 \mathrm{~cm} \\
\mathrm{STD}^{\mathrm{St}}=9.0 \mathrm{~cm}, \mathrm{STD}^{\mathrm{GS}}=6.5 \mathrm{~cm}\end{array}$} & \multicolumn{3}{|c|}{$\begin{aligned} \operatorname{mean}^{\mathrm{St}} & =11.9^{\circ} \mathrm{C} \\
\mathrm{STD}^{\mathrm{St}} & =2.3^{\circ} \mathrm{C}\end{aligned}$} \\
\hline & bias $^{S t}$ & $\mathrm{RMSE}^{\mathrm{St}}$ & bias $^{G S}$ & $\mathrm{RMSE}^{\mathrm{GS}}$ & STD & bias $^{S t}$ & $\mathrm{RMSE}^{\mathrm{St}}$ & STD \\
\hline CLM4.5 & 11.5 & 18.1 & 14.3 & 18.1 & 5.8 & 2.3 & 4.1 & 2.2 \\
\hline CoLM & 15.6 & 21.4 & 17.8 & 22.1 & 9.8 & 2.7 & 3.7 & 2.4 \\
\hline ISBA & 13.0 & 18.8 & 15.7 & 19.8 & 9.5 & -8.4 & 9.1 & 0.9 \\
\hline JULES & -4.1 & 14.1 & -1.3 & 12.8 & 7.7 & -0.8 & 4.2 & 3.2 \\
\hline LPJ-GUESS & -5.3 & 17.3 & -2.5 & 16.0 & 5.0 & -0.7 & 3.7 & 1.7 \\
\hline MIROC-ESM & -0.4 & 17.9 & 1.9 & 14.0 & 6.3 & -4.9 & 6.7 & 2.0 \\
\hline ORCHIDEE & -8.7 & 16.5 & -5.3 & 15.3 & 6.9 & -5.2 & 6.0 & 1.9 \\
\hline UVic & -3.7 & 18.9 & -0.5 & 16.8 & 9.4 & -5.1 & 6.5 & 1.4 \\
\hline UW-VIC & 12.5 & 19.8 & 15.0 & 20.0 & 10.4 & -1.3 & 4.8 & 2.1 \\
\hline
\end{tabular}

\subsubsection{Snow depth}

The broad-scale spatial snow depth $\left(d_{\text {snow }}\right)$ patterns are similar across the models and show general agreement with the observed patterns (Fig. 6). The well-pronounced areas of maximum winter $d_{\text {snow }}(50-100 \mathrm{~cm})$ are in Scandinavia, the Urals, the West Siberian Plain, Central Siberian Highlands, the Far East, Alaska, Labrador Peninsula and Isle of Newfoundland. However, large regional cross-model variability is obvious. Some models (JULES, LPJ-GUESS, ORCHIDEE, UVic) underestimate $d_{\text {snow }}$, while others (CLM4.5, CoLM, ISBA, UW-VIC) overestimate it (Fig. 6; Table 3). The model biases are quite similar with respect to station observations and GlobSnow data. It should be noted that the models do not account for snowdrift. However, redistribution of snow due to wind is an important aspect, which makes comparison between in situ measured and modelled snow depths difficult (e.g. Vionnet et al., 2013; Sturm and Stuefer, 2013; Gisnas et al., 2014).

Precipitation/snowfall cross-model differences cannot be the primary explanation for these $d_{\text {snow }}$ differences since some models (JULES, MIROC-ESM, ORCHIDEE) have positive bias in precipitation $\left(>0.2 \mathrm{~mm} \mathrm{day}^{-1}\right.$, Table S2) but simulate much lower $d_{\text {snow }}$ compared to other models (Figs. 6, S6, S7, Table 3). Cross-model differences in the interannual variability of winter precipitation do not translate simply to corresponding differences in the interannual $d_{\text {snow }}$ variability (not shown). For example, UVic calculates the (unrealistically) largest interannual $d_{\text {snow }}$ variability in the boreal European permafrost region, which is not reflected in the precipitation variability. These results indicate that the simulated snow depth is a function of both the prescribed winter precipitation and the model's snow energy and water balance.

\subsection{Model processes}

We have shown that the cross-model spread in the representation of snow insulation effects (Sects. 3.1, 3.2) cannot predominantly be explained by differences in the forcing data (Sect. 4.1), but to a large extent is due to the representation of snow processes in the models. By considering the relationship plots (Figs. 1, 4 and 5) and conditional PDFs (Fig. 2), we were able to categorise the models in terms of their snow insulation performance. In this section we discuss the influence of the different snow parameterisations in the models.

Models with better performance (CLM4.5, CoLM, JULES) apply multilayer snow schemes. This allows them to simulate more realistic (stronger) insulation because they consider the snowpack's vertical structure and variability. They calculate the energy and mass balance in each snow layer, are able to capture nonlinear profiles of snow temperature and can also account for thermal insulation within the snowpack such as when the upper layer thermally insulates the lower layers (e.g. Dutra et al., 2012). These models also incorporate storage and refreezing of liquid water within the snow and parameterise wet-snow metamorphism, snow compaction and snow thermal conductivity (Table 1), which have been found to be among the most important processes for good snow depth and surface soil temperature simulation (e.g. Wang et al., 2013).

An underestimated snow depth directly leads to insulation that is too weak in JULES, LPJ-GUESS, ORCHIDEE and UVic (Fig. 6, Table 3). However only in ORCHIDEE and UVic does this lead to a significant underestimation of $\Delta T$ 
(Table 3, Fig. S8), indicating bias compensation in the two other models. Thus, compensating error effects occur due to snow density and conductivity (Fig. S9, Table 1), which impact snow thermal insulation.

Our analysis showed that two models (ISBA, UVic) have $T_{\text {soil }}$ vs. $T_{\text {air }}$ correlation that are too high, indicating that they do not represent the modulation of the $T_{\text {soil }}$ vs. $T_{\text {air }}$ relationship by snow depth (Fig. 4). This is consistent with their underestimation of $\Delta T$ (Figs. 1, 2, S8, Table 3). In UVic, the snowpack is treated not as a separate layer but as an extension of the top soil layer and a combined surface-to-soil thermal conductivity is calculated (Table 1). Such a scheme largely negates or reduces the insulating capacity of snow (Slater et al., 2001). Koven et al. (2013) noted that such a scheme simulates very little warming of soil and sometimes even cooling. The slightly underestimated snow depth (Table 3, Fig. 6) contributes (but not as the primary factor) to reduced snow insulation, as reported for UVic (Avis, 2012).

ISBA strongly underestimates $\Delta T$, while strongly overestimating $d_{\text {snow }}$, compared with the observations (Table 3, Fig. 6). However, ISBA uses the same atmospheric forcing data as JULES (accordingly the air temperature and precipitation are quite similar; Table S2). Also, the model's snow density $\left(150-250 \mathrm{~kg} \mathrm{~m}^{-3}\right)$ is similar to other models (CLM45, CoLM, JULES; Fig. S9) and in agreement with Zhong et al. (2014), who report snow density values of 180 $250 \mathrm{~kg} \mathrm{~m}^{-3}$ for tundra/taiga and $156-193 \mathrm{~kg} \mathrm{~m}^{-3}$ for alpine snow classes in winter. This apparent contradiction comes from the parameterisation of snow cover fraction within each grid cell (SCF). The version of ISBA used here calculates a unique superficial soil temperature whether or not the soil is covered by snow and all the energy and radiative fluxes are area-weighted by SCF (Eqs. 7 and 20 in Douville et al., 1995). In order to get reasonable albedos in snow-covered forests, as is necessary when ISBA is coupled to the CNRM$\mathrm{CM}$ climate model, the parameterisation gives very low SCF in the boreal forest (between 0.2 and 0.5). Hence, snow insulates only 20 to $50 \%$ of the grid cell, despite fairly high snow depths. The heat fluxes from the snow-covered fraction are averaged with the fluxes from the snow-free surface, strongly concealing the actual insulating effect of snow and underestimating it over the grid cell. Using the detailed snow model Crocus (Brun et al., 1992; Vionnet et al., 2012) with a SCF equal to $100 \%$ leads to an almost perfect simulation of near-surface soil temperature over northern Eurasia (Brun et al., 2013). A similar experiment with ISBA and a SCF equal to $100 \%$ (Decharme et al., 2016) leads to good performances showing that the low $\Delta T$ in ISBA, despite high snow depth in the present study, is mostly due to this subgrid snow fraction. Decharme et al. (2016) still showed that the ISBA results are further improved by updating the snow albedo and snow densification parameterisation.

Interestingly, the ORCHIDEE performance in simulating snow depth and $\Delta T$ is similar to UVic (underestimation of $d_{\text {snow }}$ and $\Delta T$; Table 3$)$. However, ORCHIDEE can better
Table 4. Permafrost area, defined as maximum seasonal active layer thickness < $3 \mathrm{~m}$ in 1960 (Mc Guire et al., 2016). The IPA map estimate is 16 million $\mathrm{km}^{2}$ (Brown et al., 1997; Slater and Lawrence, 2013).

\begin{tabular}{llr}
\hline $\begin{array}{l}\text { Land surface } \\
\text { Model }\end{array}$ & $\begin{array}{l}\text { Snow insulation } \\
\text { skill }\end{array}$ & $\begin{array}{r}\text { Permafrost } \\
\text { area }\left(10^{6} \mathrm{~km}^{2}\right)\end{array}$ \\
\hline CLM4.5 & High & 15.77 \\
CoLM & High & 7.62 \\
ISBA & Low & 20.86 \\
JULES & High & 13.19 \\
LPJ-GUESS & Medium & 17.41 \\
MIROC-ESM & Medium & 13.02 \\
ORCHIDEE & Medium & 20.01 \\
UVic & Low & 16.47 \\
UW-VIC & Medium & 17.56 \\
\hline
\end{tabular}

represent the observed $T_{\text {soil }}$ vs. $T_{\text {air }}$ relationship and its modulation due to the snow pack. ORCHIDEE employs, similarly to UVic, a fixed snow density and thermal conductivity. However, in contrast to UVic, ORCHIDEE applies a multilayer scheme and simulates heat diffusion in the snowpack in up to seven discrete layers (Table 1; Koven et al., 2009). This helps to resolve the snow thermal gradients between the top and the base of the snow cover and might explain how some of the snow insulation effects are reasonably represented in ORCHIDEE, despite the simpler treatment of temperature diffusion.

\section{Permafrost area}

Snow cover plays an important role in modulating the variations of soil thermodynamics, hence near-surface permafrost extent (e.g. Park et al., 2015). Here we evaluate whether there is a simple relationship between the simulated Northern Hemisphere permafrost area and the sophistication and ability of the snow insulation component in the LSM to match the observed snow packs. The simulated near-surface permafrost area varies greatly across the nine models in the hindcast simulation (1960-2009; Table 4). Some of the better-performing snow insulation effect models (CLM4.5, JULES) simulate a near-surface permafrost area of 13.19 to 15.77 million $\mathrm{km}^{2}$, which is comparable with the IPA map estimate $\left(16.2\right.$ million $\mathrm{km}^{2}$; Brown et al., 1997; Slater and Lawrence, 2013). CoLM and ORCHIDEE, identified as reasonable models with respect to snow insulation, simulate much lower $\left(7.62\right.$ million $\left.\mathrm{km}^{2}\right)$ and higher (20.01 million $\mathrm{km}^{2}$ ) areas respectively. The main deficiency of CoLM is its too-shallow soil depth $(3.4 \mathrm{~m})$ compared with CLM4.5 $(45.1 \mathrm{~m})$, despite having very similar snow modules (Table 1). However, ISBA, one of the two models that showed rather limited skill in representing snow insulation effects, also significantly overestimate permafrost area 
(20.86 million $\left.\mathrm{km}^{2}\right)$. This is inconsistent with previous studies (e.g. Vavrus, 2007; Koven et al., 2013), which concluded that the first-order control on modelled near-surface permafrost distribution is the representation of the air-to-surface soil temperature difference. Table 4 shows that the situation is more complex and that snow insulation simulation is not the dominant factor in a good permafrost extent simulation. When the land surface models with poor snow models are eliminated, the remaining models' simulated permafrost area show little or no relationship with the performance of the snow insulation component, because several other factors such as differences in the treatment of soil organic matter, soil hydrology, surface energy calculations, model soil depth and vegetation also provide important controls on the simulated permafrost distribution (e.g. Marchenko and Etzelmüller, 2013).

\section{Summary and conclusions}

The aim of this work was to evaluate how state-of-the-art LSMs capture the observed relationship between winter nearsurface soil and air temperatures $\left(T_{\text {soil }}, T_{\text {air }}\right)$ and their modulation by snow depth $\left(d_{\text {snow }}\right)$ and climate regime. We presented some benchmarks to evaluate model performance. The presented relation diagrams of $T_{\text {soil }}$ and the difference between $T_{\text {soil }}$ and $T_{\text {air }}$ regarding snow depth allow for a much better assessment, used to reveal structural issues of the models, than a direct point-by-point comparison with station observations. The results are based on the comparison of LSMs with a comprehensive Russian station data set.

We see large differences across the models in their mean air-soil temperature difference $(\Delta T)$ of 3 to $14^{\circ} \mathrm{C}$, in the sensitivity of near-surface soil temperature to air temperature ( $T_{\text {soil }}$ vs. $T_{\text {air }} ; 0.49$ to $0.96{ }^{\circ} \mathrm{C}^{\circ} \mathrm{C}^{-1}$ for shallow snow, 0.13 to $0.93{ }^{\circ} \mathrm{C}^{\circ} \mathrm{C}^{-1}$ for thick snow) and in the increase of $\Delta T$ with increasing snow depth (modal value of $\Delta T$ PDF: 0 to $10^{\circ} \mathrm{C}$ for shallow snow, 5 to $21^{\circ} \mathrm{C}$ for thick snow). Most of the nine models compare to the observations reasonably well (observations: $\Delta T=12^{\circ} \mathrm{C}$, modal $\Delta T$ values of $5{ }^{\circ} \mathrm{C}$ for shallow snow and of $14^{\circ} \mathrm{C}$ for thick snow, $T_{\text {soil }}$ vs. $T_{\text {air }}=0.62^{\circ} \mathrm{C}^{\circ} \mathrm{C}^{-1}$ for shallow snow, $T_{\text {soil }}$ vs. $T_{\text {air }}=0.21^{\circ} \mathrm{C}^{\circ} \mathrm{C}^{-1}$ for thick snow). Several models also capture the modulation by air temperature condition (larger increase in $\Delta T$ with increasing $d_{\text {snow }}$ under colder conditions) and display the control of snow depth on $T_{\text {soil }}$ (weaker $T_{\text {soil }}$ vs. $T_{\text {air }}$ relationship under thicker snow). However, while they generally capture these observed relationships, their strength can differ in the individual models. Two models (ISBA, UVic) show the largest deficits in snow insulation effects and cannot separate the $\Delta T$ regimes neither for different snow depths nor for different air temperature conditions.

This study uses the ensemble of models to document model performance with respect to the $T_{\text {soil }}$ vs. $T_{\text {air }}$ relationship, and to identify those with better performance, rather than to quantify the best model. We were able to attribute performance strength/weakness to snow model features and complexity. Models with better performance apply multilayer snow schemes and consider complex snow processes (e.g. storage and refreezing of liquid water within the snow, wet snow metamorphism, snow compaction). Those models which show limited skill in snow insulation representation (underestimated $\Delta T$, very weak dependency of $\Delta T$ on $d_{\text {snow }}$, almost unity ratio of $T_{\text {soil }}$ vs. $T_{\text {air }}$ ) have some deficiencies or oversimplification in the simulation of heat transfer in snow and soil layer, particularly in the representation of snow depth and density (conductivity). We also emphasise that compensation of errors in snow depth and conductivity can occur. For example, an excessive correlation between $T_{\text {soil }}$ and $T_{\text {air }}$ can be attributed to excessively high thermal conductivity even when the snow depth is correctly (or over) simulated. This finding underscores the need for detailed model evaluations using multiple independent performance metrics to ensure that the models get the right functionality for the right reason. It should be noted that the treatment of ground properties, particularly soil organic matter and soil moisture/ice content, also affect the simulated winter ground temperatures. The specific evaluation of these individual processes is more robustly investigated with experiments conducted for individual models (e.g. recently, Wang et al., 2013; Gubler et al., 2013; Decharme et al., 2016).

Snow and its insulation effects are critical for accurately simulating soil temperature and permafrost at high latitudes. The simulated near-surface permafrost area varies greatly across the nine models (from 7.62 to 20.86 million $\mathrm{km}^{2}$ ). However, it is hard to find a clear relationship between the performance of the snow insulation in the models and the simulated area of permafrost, because several other factors (e.g. related to soil depth and properties and vegetation cover) also control the simulated permafrost distribution.

\section{Data availability}

The data will be made available through the National Snow and Ice Data Center (NSIDC; http://nsidc.org); the contact person is Kevin Schaefer (kevin.schaefer@nsidc.org).

\section{The Supplement related to this article is available online at doi:10.5194/tc-10-1721-2016-supplement.}

Author contributions. Annette Rinke developed the idea that lead to this paper, Wenli Wang and Annette Rinke carried out research, John C. Moore contributed ideas, Annette Rinke, John C. Moore, Wenli Wang, and Duoying Ji wrote the paper and all authors discussed the results and commented on the paper at all stages. 
Acknowledgements. This study was supported by the Permafrost Carbon Vulnerability Research Coordination Network, which is funded by the US National Science Foundation (NSF). Any use of trade, firm, or product names is for descriptive purposes only and does not imply endorsement by the US Government. Eleanor J. Burke was supported by the Joint UK DECC/Defra Met Office Hadley Centre Climate Program (GA01101). Eleanor J. Burke, Shushi Peng, Philippe Ciais and Gerhard Krinner were supported by the European Union Seventh Framework Program (FP7/2007-2013) under grant agreement no. 282700. Theodore J. Bohn was supported by grant 1216037 from the NSF Science, Engineering and Education for Sustainability (SEES) Post-Doctoral Fellowship program. Bertrand Decharme, Ramdane Alkama and Christine Delire were supported by the French Agence Nationale de la Recherche under agreement ANR-10-CEPL-012-03. This research was sponsored by the integrated approaches and impacts, China Global Change Program (973 Project), National Basic Research Program of China Grant 2015CB953602 and the National Natural Science Foundation of China Grant 40905047. We also thank the editor and reviewers for their comments which improved the manuscript.

Edited by: J. Boike

Reviewed by: two anonymous referees

\section{References}

Anderson, E. A.: A point energy and mass balance model of a snow cover, Office of Hydrology, National Weather Service, Silver Spring, Maryland, NOAA Technical Report NWS 19, 1976.

Andreadis, K., Storck, P., and Lettenmaier, D. P.: Modeling snow accumulation and ablation processes in forested environments, Water Resour. Res., 45, W05429, doi:10.1029/2008WR007042, 2009.

Anisimov, O. A. and Sherstiukov A. B.: Evaluating the effect of environmental factors on permafrost factors in Russia, Earth's Cryosphere, 90-99, 2016.

Avis, C. A.: Simulating the present-day and future distribution of permafrost in the UVic Earth System Climate Model, Dissertation, University of Victoria, Canada, 274 pp., 2012.

Bartlett, P. A., MacKay, M. D., and Verseghy, D. L.: Modified snow algorithms in the Canadian Land Surface Scheme: model runs and sensitivity analysis at three boreal forest stands, Atmos. Ocean, 44, 207-222, 2006.

Best, M. J., Pryor, M., Clark, D. B., Rooney, G. G., Essery, R. L. H., Ménard, C. B., Edwards, J. M., Hendry, M. A., Porson, A., Gedney, N., Mercado, L. M., Sitch, S., Blyth, E., Boucher, O., Cox, P. M., Grimmond, C. S. B., and Harding, R. J.: The Joint UK Land Environment Simulator (JULES), model description Part 1: Energy and water fluxes, Geosci. Model Dev., 4, 677-699, doi:10.5194/gmd-4-677-2011, 2011.

Boone, A. and Etchevers, P.: An intercomparison of three snow schemes of varying complexity coupled to the same land-surface model: Local scale evaluation at an Alpine site, J. Hydrometeorol., 2, 374-394, 2001.

Brown, J., Ferrians, O. J., Heginbottom, J. A., and Melnikov, S. E.: International Permafrost Association Circum-Arctic Map of Permafrost and Ground Ice Conditions, scale 1:10000 000,
Circum-Pacific Map Series, USGS Circum-Pacific Map Series, 45 pp., 1997.

Brun, E., David, P., Sudul, M., and Brunot, G.: A numerical model to simulate snow cover stratigraphy for operational avalanche forecasting, J. Glaciol., 38, 13-22, 1992.

Brun, E., Vionnet, V., Boone, A., Decharme, B., Peings, Y., Valette, R., Karbou, F., and Morin, S.: Simulation of northern Eurasian local snow depth, mass and density using a detailed snowpack model and meteorological reanalysis, J. Hydrometeorol., 14, 203-214, doi:10.1175/jhm-d-12-012.1, 2013.

Cook, B. I., Bonan, G. B., Levis, S., and Epstein, H. E.: The thermoinsulation effect of snow cover within a climate model, Clim. Dynam., 31, 107-124, doi:10.1007/s00382-007-0341-y, 2008.

Dai, Y., Zeng, X., Dickinson, R. E., Baker, I., Bonan, G. B., Bosilovich, M. G., Denning, A. S., Dirmeyer, P. A., Houser, P. R., Niu, G., Oleson, K. W., Schlosser, C. A., and Yang, Z.: The Common Land Model (CLM), B. Am. Meteorol. Soc., 84, 10131023, doi:10.1175/BAMS-84-8-1013, 2003.

Dankers, R., Burke, E. J., and Price, J.: Simulation of permafrost and seasonal thaw depth in the JULES land surface scheme, The Cryosphere, 5, 773-790, doi:10.5194/tc-5-773-2011, 2011.

Decharme, B., Brun, E., Boone, A., Delire, C., Le Moigne, P., and Morin, S.: Impacts of snow and organic soils parameterization on northern Eurasian soil temperature profiles simulated by the ISBA land surface model, The Cryosphere, 10, 853-877, doi:10.5194/tc-10-853-2016, 2016.

Douville, H., Royer, J. F., and Mahfouf, J. F.: A new snow parameterization for the Meteo-France climate model, Part 1: Validation in stand-alone experiments, Clim. Dynam., 12, 21-35, 1995.

Dutra, E., Viterbo, P., Miranda, P. M. A., and Balsamo, G.: Complexity of snow schemes in a climate model and its impact on surface energy and hydrology, J. Hydrometeorol., 13, 521-538, doi:10.1175/jhm-d-11-072.1, 2012.

Dutra, E., Balsamo, G., Viterbo, P., Miranda, P. M. A., Beljaars, A., Schär, C., and Elder, K.: An improved snow scheme for the ECMWF land surface model: description and offline validation, J. Hydrometeorol., 11, 899-916, 2010.

Essery, R., Morin, S., Lejeune, Y., and Ménard, C. B.: A comparison of 1701 snow models using observations from an alpine site, Adv. Water Resour., 55, 131-148, doi:10.1016/j.advwatres.2012.07.013, 2013.

Essery, R. L. H., Rutter, N., Pomeroy, J., Baxter, R., Staehli, M., Gustafsson, D., Barr, A., Bartlett, P., and Elder, K.: SnowMIP2: An evaluation of forest snow process simulations, B. Am. Meteorol. Soc., 90, 1120-1135, doi:10.1175/2009BAMS2629.1, 2009.

Ge, Y. and Gong, G.: Land surface insulation response to snow depth variability, J. Geophys. Res., 115, D08107, doi:10.1029/2009JD012798, 2010.

Gerten, D., Schaphoff, S., Haberlandt, U., Lucht, W., and Sitch, S.: Terrestrial vegetation and water balance: Hydrological evaluation of a dynamic global vegetation model, J. Hydrol., 286, 249-270, 2004.

Gisnås, K., Westermann, S., Schuler, T. V., Litherland, T., Isaksen, K., Boike, J., and Etzelmüller, B.: A statistical approach to represent small-scale variability of permafrost temperatures due to snow cover, The Cryosphere, 8, 2063-2074, doi:10.5194/tc-82063-2014, 2014.

Gouttevin, I., Menegoz, M., Domine, F., Krinner, G., Koven, C.D., Ciais, P., Tarnocai, C., and Boike, J.: How the insulat- 
ing properties of snow affect soil carbon distribution in the continental pan-Arctic area, J. Geophys. Res., 117, G02020, doi:10.1029/2011JG001916, 2012.

Gubler, S., Endrizzi, S., Gruber, S., and Purves, R. S.: Sensitivities and uncertainties of modeled ground temperatures in mountain environments, Geosci. Model Dev., 6, 1319-1336, doi:10.5194/gmd-6-1319-2013, 2013.

Jafarov, E. E., Nicolsky, D. J., Romanovsky, V. E., Walsh, J. E., Panda, S. K., and Serreze, M. C.: The effect of snow: How to better model ground surface temperatures, Cold Regions Sci. Technol., 102, 63-77, doi:10.1016/j.coldregions.2014.02.007, 2014.

Ji, D., Wang, L., Feng, J., Wu, Q., Cheng, H., Zhang, Q., Yang, J., Dong, W., Dai, Y., Gong, D., Zhang, R.-H., Wang, X., Liu, J., Moore, J. C., Chen, D., and Zhou, M.: Description and basic evaluation of Beijing Normal University Earth System Model (BNU-ESM) version 1, Geosci. Model Dev., 7, 2039-2064, doi:10.5194/gmd-7-2039-2014, 2014.

Jordan, R.: A one-dimensional temperature model for a snow cover, technical documentation for SNTHERM.89, US Army Cold Regions Research and Engineering Laboratory, Hanover, NH, 49 pp., 1991.

Karunaratne, K. C. and Burn, C. R.: Freezing n-factors in discontinuous permafrost terrain, Takhini River, Yukon Territory, Canada, Proc. 8th Int. Conf. on Permafrost, Zurich, 519-524, 2003.

Klehmet, K., Geyer, B., and Rockel, B.: A regional climate model hindcast for Siberia: analysis of snow water equivalent, The Cryosphere, 7, 1017-1034, doi:10.5194/tc-7-1017-2013, 2013.

Koven, C. D., Riley, W. J., and Stern, A.: Analysis of Permafrost Thermal Dynamics and Response to Climate Change in the CMIP5 Earth System Models, J. Climate, 26, 1877-1900, doi:10.1175/JCLI-D-12-00228.1, 2013.

Koven, C., Friedlingstein, P., Ciais, P., Khvorostyanov, D., Krinner, G., and Tarnocai, C.: On the formation of high-latitude soil carbon stocks: Effects of cryoturbation and insulation by organic matter in a land surface model, Geophys. Res. Lett., 36, L21501, doi:10.1029/2009GL040150, 2009.

Langer, M., Westermann, S., Heikenfeld, M., Dorn, W., and Boike, J.: Satellite-based modeling of permafrost temperatures in a tundra lowland landscape, Remote Sens. Environ., 135, 12-24, doi:10.1016/j.rse.2013.03.011, 2013.

Lawrence, D. M. and Slater, A. G.: The contribution of snow condition trends to future ground climate, Clim. Dynam., 34, 969-981, doi:10.1007/s00382-009-0537-4, 2010.

Marchenko, S. and Etzelmüller, B.: Permafrost: Formation and Distribution, Thermal and Mechanical Properties, 8, Academic Press, San Diego, 202-222, 2013.

McGuire, A. D., Koven, C., Lawrence, D. M., Clein, J. S., Xia, J., Beer, C., Burke, E., Chen, G., Chen, X., Delire, C., Jafarov, E., MacDougall, A. H., Marchenko, S., Nicolsky, D., Peng, S., Rinke, A., Saito, K., Zhang, W., Alkama, R., Bohn, T. J., Ciais, P., Decharme, B., Ekici, A., Gouttevin, I., Hajima, T., Hayes, D. J., Ji, D., Krinner, G., Lettenmaier, D. P., Luo, Y., Miller, P. A., Moore, J. C., Romanovsky, V., Schädel, C., Schaefer, K., Schuur, E. A. G., Smith, B., Sueyoshi, T., and Zhuang, Q.: A modelbased analysis of the vulnerability of carbon in the permafrost region between 1960 and 2009, Global Biogeochem. Cy., 30, 123, doi:10.1002/2016GB005405, 2016.

Meissner, K. J., Weaver, A. J., Matthews, H. D., and Cox, P. M.: The role of land-surface dynamics in glacial inception: A study with the UVic earth system model, Clim. Dynam., 21, 515-537, 2003.

Morse, P. D., Burn, C. R., and Kokelj, S. V.: Influence of snow on near-surface ground temperatures in upland and alluvial environments of the outer Mackenzie Delta, Northwest Territories, Can. J. Earth Sci., 49, 895-913, doi:10.1139/E2012-012, 2012.

Muskett, R.: Remote sensing, model-derived and ground measurements of snow water equivalent and snow density in Alaska, Int. J. Geosci., 3, 1127-1136, doi:10.4236/ijg.2012.35114, 2012.

Nicolsky, D. J., Romanovsky, V. E., Alexeev, V. A., and Lawrence, D. M.: Improved modelling of permafrost dynamics in a GCM land-surface scheme, Geophys. Res. Lett., 34, L08501, doi:10.1029/2007GL029525, 2007.

Oleson, K. W., Lawrence, D. M., Bonan, G. B., Drewniak, B., Huang, M., Koven, C. D., Levis, S., Li, F., Riley, W. J., Subin, Z. M., Swenson, S. C., Thornton, P. E., Bozbiyik, A., Fisher, R., Kluzek, E., Lamarque, J.-F., Lawrence, P. J., Leung, L. R., Lipscomb, W., Muszala, S., Ricciuto, D. M., Sacks, W., Sun, Y., Tang, J., and Yang, Z.-L.: Technical description of version 4.5 of the Community Land Model (CLM), NCAR Technical Note NCAR/TN-503+STR, doi:10.5065/D6RR1W7M, 2013.

PaiMazumder, D., Miller, J., Li, Z., Walsh, J. E., Etringer, A., McCreight, J., Zhang, T., and Mölders, N.: Evaluation of Community Climate System Model soil temperatures using observations from Russia, Theor. Appl. Climatol., 94, 187-213, 2008.

Park, H., Fedorov, A. N., Zheleznyak, M. N., Konstantinov, P. Y., and Walsh, J. E.: Effect of snow cover on pan-Arctic permafrost thermal regimes, Clim. Dynam., 44, 2873-2895, doi:10.1007/s00382-014-2356-5, 2015.

Park, H., Sherstiukov, A. B., Fedorov, A. N., Polyakov, I. V., and Walsh, J. E.: An observation-based assessment of the influences of air temperature and snow depth on soil temperature in Russia, Environ. Res. Lett., 9, 1-7, doi:10.1088/1748-9326/9/6/064026, 2014.

Pavlov, A. V. and Malkova, G. V.: Small-scale mapping of trends of the contemporary ground temperature changes in the Russian North, Earth's Cryosphere, 13, 32-39, 2009.

Peng, S., Ciais, P., Krinner, G., Wang, T., Gouttevin, I., McGuire, A., Lawrence, D., Burke, E., Chen, X., Decharme, B., Koven, C., MacDougall, A., Rinke, A., Saito, K., Zhang, W., Alkama, R., Bohn, T. J., Delire, C., Hajima, T., Ji, D., Lettenmaier, D. P., Miller, P. A., Moore, J. C., Smith, B., and Sueyoshi, T.: Simulated high-latitude soil thermal dynamics during the past four decades, The Cryosphere, 10, 1-14, doi:10.5194/tc-10-1-2016, 2015.

Rawlins, M. A., McGuire, A. D., Kimball, J. S., Dass, P., Lawrence, D., Burke, E., Chen, X., Delire, C., Koven, C., MacDougall, A., Peng, S., Rinke, A., Saito, K., Zhang, W., Alkama, R., Bohn, T. J., Ciais, P., Decharme, B., Gouttevin, I., Hajima, T., Ji, D., Krinner, G., Lettenmaier, D. P., Miller, P., Moore, J. C., Smith, B., and Sueyoshi, T.: Assessment of model estimates of landatmosphere $\mathrm{CO}_{2}$ exchange across Northern Eurasia, Biogeosciences, 12, 4385-4405, doi:10.5194/bg-12-4385-2015, 2015.

Romanovsky, V. E., Sazonova, T. S., Balobaev, V. T., Shender, N. I., and Sergueev, D. O.: Past and recent changes in air and permafrost temperatures in eastern Siberia, Global Planet. Change, 56, 399-413, doi:10.1016/j.gloplacha.2006.07.022, 2007.

Saha, S., Rinke, A., Dethloff, K., and Kuhry, P.: Influence of complex land surface scheme on Arctic climate simulations, J. Geophys. Res., 111, D22104, doi:10.1029/2006JD007188, 2006. 
Schaefer, K., Zhang, T., Bruhwiler, L., and Barrett, A. P.: Amount and timing of permafrost carbon release in response to climate warming, Tellus B, 63, 165-180, doi:10.1111/j.16000889.2011.00527.x, 2011.

Schuur, E. A. G., Bockheim, J., Canadell, J. G., Euskirchen, E., Field, C. B., Goryachkin, S. V., Hagemann, S., Kuhry, P., Lafleur, P. M., Lee, H., Mazhitova, G., Nelson, F. E., Rinke, A., Romanovsky, V. E., Shiklomanov, N., Tarnocai, C., Venevsky, S., Vogel, J. G., and Zimov, S. A.: Vulnerability of permafrost carbon to climate change: Implications for the global carbon cycle, Bioscience, 58, 701-714, doi:10.1641/b580807, 2008.

Sherstiukov A.: Climate Change and its Impacts in the Permafrost Zone of Russia, RIHMI-WDC, Obninsk, 127 pp., 2009.

Sherstiukov, A.: Dataset of daily soil temperature up to $320 \mathrm{~cm}$ depth based on meteorological stations of Russian Federation, RIHMI-WDC, 176, 224-232, 2012a.

Sherstiukov, A.: Statistical quality control of soil temperature dataset, RIHMI-WDC, 176, 224-232, 2012b.

Singh, V. P., Singh, P., and Haritashya, U.: Encyclopedia of snow, ice and glaciers, Springer, 1240 pp., 2011.

Slater, A. G., Schlosser, C. A., and Desborough, C. E.: The representation of snow in land-surface schemes: Results from PILPS 2(d), J. Hydrometeorol., 2, 7-25, 2001.

Slater, A. and Lawrence, D.: Diagnosing present and future permafrost from climate models, J. Climate, 26, 5608-5623, doi:10.1175/JCLI-D-12-00341.1, 2013.

Smith, M. W. and Riseborough, D. W.: Climate and the limits of permafrost: a zonal analysis, Permafrost Periglac. Process., 13, 115, doi:10.1002/ppp.410, 2002.

Sokratov, S. A. and Barry, R. G.: Intraseasonal variation in the thermoinsulation effect of snow cover on soil temperatures and energy balance, J. Geophys. Res., 107, D104093, doi:10.1029/2001JD000489, 2002.

Sturm, M. and Stuefer, S.: Wind-blown flux rates derived from drifts at arctic snow fences, J. Glaciol., 59, 21-34, 2013.

Swenson, S. C. and Lawrence, D. M.: A new fractional snowcovered area parameterization for the Community Land Model and its effect on the surface energy balance, J. Geophys. Res., 117, D21107, doi:10.1029/2012JD018178, 2012.

Takala, M., Luojus, K., Pulliainen, J., Derksen, C., Lemmetyinen, J., Karna, J. P., Koskinen, J., and Bojkov, B.: Estimating Northern Hemisphere snow water equivalent for climate research through assimilation of space-borne radiometer data and ground-based measurements, Remote Sens. Environ., 115, 3517-3529, 2011.
Vavrus, S. J.: The role of terrestrial snow cover in the climate system, Clim. Dynam., 20, 73-88, doi:10.1007/s00382-007-0226-0, 2007.

Vionnet, V., Brun, E., Morin, S., Boone, A., Faroux, S., Le Moigne, P., Martin, E., and Willemet, J.-M.: The detailed snowpack scheme Crocus and its implementation in SURFEX v7.2, Geosci. Model Dev., 5, 773-791, doi:10.5194/gmd-5-773-2012, 2012.

Vionnet, V., Guyomarch, G., Martin, E., Durand, Y., Bellot, H., Bel, C., and Puglièse, P.: Occurrence of blowing snow events at an alpine site over a 10-year period: observations and modelling, Adv. Water Resour., 55, 53-63, 2013.

Von Storch, H. and Zwiers, F. W.: Statistical Analysis in Climate Research, Cambridge University Press, Cambridge, 484 pp., 1999.

Wang, T., Ottle, C., Boone, A., Ciais, P., Brun, E., Morin, S., Krinner, G., Piao, S., and Peng, S.: Evaluation of an improved intermediate complexity snow scheme in the ORCHIDEE land surface model, J. Geophys. Res., 118, 6064-6079, doi:10.1002/jgrd.50395, 2013.

Wania, R., Ross, I., and Prentice, I. C.: Integrating peatlands and permafrost into a dynamic global vegetation model: 2. Evaluation and sensitivity of vegetation and carbon cycle processes, Global Biogeochem. Cy., 23, GB3015, doi:10.1029/2008GB003413, 2009.

Woo, M., Heron, R., Marsh, P., and Steer, P.: Comparison of weather station snowfall with winter snow accumulation in high arctic basins, Atmos. Ocean, 21, 312-325, doi:10.1080/07055900.1983.9649171, 1983.

Zhang, T.: Influence of the seasonal snow cover on the ground thermal regime: An overview, Rev. Geophys., 43, RG4002, doi:10.1029/2004RG000157, 2005.

Zhang, T., Osterkamp, T. E., and Stamnes, K.: Influence of the depth hoar layer of the seasonal snow cover on the ground thermal regime, Water Resour. Res., 32, 2075-2086, doi:10.1029/96WR00996, 1996.

Zhong, X., Zhang, T., and Wang, K.: Snow density climatology across the former USSR, The Cryosphere, 8, 785-799, doi:10.5194/tc-8-785-2014, 2014. 